\title{
Belgian colonial rule and lagging elite formation
}

\section{The hesitant colonial power (1908-1940)}

The Belgians were in many ways "reluctant colonialists." ${ }^{1}$ The Belgian Empire comprised just one geographically contiguous colonial territory, fifty-seven times the size of Belgium, with a linguistically, ethnically and culturally heterogeneous population totalling eleven million people prior to the First World War. ${ }^{2}$ Situated in the middle of the African continent, the Congo bordered on the territories of other European imperial powers, arousing expansionist desires. ${ }^{3}$ The Congo Free State, established in the wake of the Berlin Conference of 18841885, was initially the private endeavour of Belgian King Leopold II; leading states tolerated it while keeping a critical eye on it. The atrocities in the Congo caused indignation around the world, ${ }^{4}$ captured iconographically in images of Congolese with their hands cut off. Leopold II's Congo Free State thus became the epitome of a murderous, exploitative state. This reign of terror was a liability inherited by the Belgian state when it took over the territory in 1908. Henceforth, the major European imperial powers questioned Belgium's moral and material capacity for "effective occupation"5 and its supposed civilizing mission. The Belgian Congo was a nervous colonial state ${ }^{6}$ fearful of interference from the other colonial powers.

In light of the international controversies over the Belgian Congo, in the metropole Belgian colonial policy aimed to achieve consensus. Only during the era of the Free State under Leopold II and on the eve of the Belgian state's takeover

1 M. Ewens, "Belgium and the Colonial Experience," Journal of Contemporary European Studies 11, no. 2 (2003): 167.

2 Vanthemsche, Belgium and the Congo, 29.

3 To the south, east and northeast of the Belgian Congo lay the British territories in Northern Rhodesia, Uganda and Sudan, to the northwest French Equatorial Africa, and to the southwest Angola, a Portuguese possession; in the east the colony bordered on German East Africa, of which Burundi and Rwanda were entrusted to Belgium as a protectorate after the First World War.

4 In addition to the killing of Lumumba, the Congo atrocities are among the best-researched topics in the history of the Belgian Congo. A major debate was ignited in the late 1990s by A. Hochschild's international bestseller King Léopold's Ghost: A Story of Greed, Terror, and Heroism in Colonial Africa (London: Mariner Books, 1998).

5 To cite the term used for the European powers' sovereignty over the colonized territories of Africa since the Berlin Conference of 1884-1885. M.E. Chamberlaine, The Scramble for Africa (London: Routledge, 1974), 54.

6 Hunt, Nervous.

Ә OpenAccess. ( 2021 Daniel Tödt, published by De Gruyter. (cc) BY This work is licensed under the Creative Commons Attribution 4.0 International License. https://doi.org/10.1515/9783110709308-002 
in 1908 did political conflicts and parliamentary discussions of colonial issues provoke heated debates; until 1945 these were limited to scattered criticisms, such as those aired by the Parti Ouvrier Belge (POB) in the inter-war period, which assailed the harsh methods used to recruit workers for the colonial economy as a perpetuation of Leopold II's rule. ${ }^{7}$ Belgium's parliamentary system amounted to a "pacifying" democracy that necessitated coalition governments and cross-party trade-offs. The notion of the "Belgian compromise" 8 can be taken quite literally. A confessional party, the Parti Catholique, was founded during the late nineteenth-century struggles between Liberals and the Catholic Church over religious schooling, and for lengthy periods this party cooperated with the Parti Libéral to form coalition governments. Both sought to achieve a "party truce" not just when it came to education policy but with respect to colonial policy as well.

The Belgian political parties were of one mind in seeking to keep metropolitan conflicts out of the colony. Even the opposition POB supported the colonial project, shared the view that the people of the Congo were among the "most primitive" in Africa and believed it was Belgium's duty to civilize them. It did call for improved living conditions and social progress, but put forward no programme of its own. ${ }^{9}$ The anticolonial movement in Belgium was weak in comparison with that in France and Great Britain. ${ }^{10}$ Though the Parti Communiste de Belgique (PCB), founded in 1921, had less political influence in the inter-war period than its counterparts in other European countries, the Belgian government feared infiltration of its colony. PCB representatives were forbidden from travelling to the Congo and their attempts to export propaganda from Antwerp with the help of Congolese sailors were unsuccessful. ${ }^{11}$ Given that the Congolese, with a few exceptions, were prohibited from entering the metropole, in contrast to the situation in France and Great Britain no anti-imperial movement that might have radiated its ideas to the colonies got off the ground among workers, former soldiers or students from the colonies. ${ }^{12}$ In the First World War Belgium

7 Seibert, Globale Wirtschaft.

8 M. Conway, The Sorrows of Belgium. Liberation and Political Reconstruction, 1944-1947 (Oxford: Oxford University Press, 2012), 6.

9 G. Vanthemsche, "De Belgische socialisten en Congo," Brood en Rozen 4 (1999).

10 On the anticolonial movement in inter-war Belgium, see L. Kottos, "L'anticolonialisme de gauche en Belgique durant l'entre-deux-guerres (1917-1939)” (Master's thesis, Université Libre Bruxelles, Brussels, 2005).

11 B. Verhaegen, “Communisme et anticommunisme au Congo (1920 - 1960),” Brood en Rozen 4 (1999).

12 On the anti-imperial milieu in Paris, see M. Goebel, Anti-Imperial Metropole. Interwar Paris and the Seeds of Third World Nationalism (New York: Cambridge University Press, 2015), on Lon- 


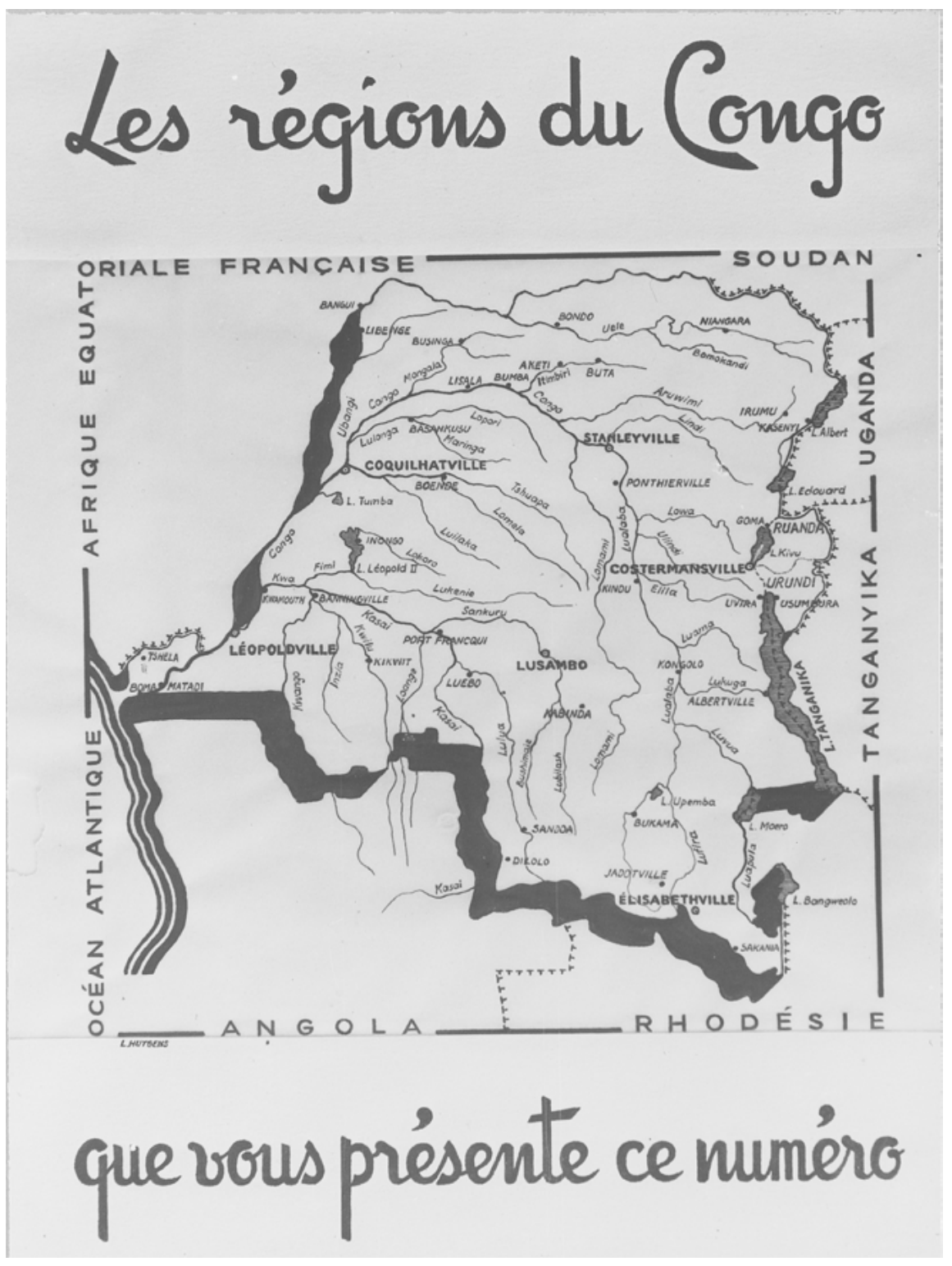

Fig. 2: The Belgian Congo, showing cities and adjacent colonies, 1946.

don see Prais, "Imperial Travelers"; M. Matera, Black London: The Imperial Metropole and Decolonization in the 20th Century (Oakland: University of California Press, 2015). 
had deployed Congolese soldiers exclusively in Africa. The Belgian Congo was thus shielded from external influences by a cordon sanitaire. ${ }^{13}$

Furthermore, the Belgian Congo's system of rule and administration was highly centralized and the preserve of a small group of actors. The colony's political course was determined by the Colonial Ministry in Brussels, whose decisions had the force of law in the Congo. ${ }^{14}$ During the years of the coalition between Liberals and Catholics, which lasted from 1908 to 1945, it was the Parti Catholique that, with the exception of a five-year period, was in charge of the Colonial Ministry. ${ }^{15}$ The party saw itself as the protector of Belgium's Catholic missions, which maintained hospitals and schools in the Congo as well as churches and whose establishment in the Free State King Leopold II had prioritised over the Protestant, mostly Anglo-Saxon competition. The predominance of the Catholic milieu in colonial policy extended to the centralized administrative apparatus below the ministerial level. The General Government in Léopoldville, nominally endowed with a small degree of executive power, ${ }^{16}$ and the provincial administrations, subject to the directives emanating from Léopoldville, were also a "bastion of Catholicism." 17 The same applied to the civil servants working in the local administrative units in the districts and territories. ${ }^{18}$

The Belgian parliament took little interest in colonial issues and failed to supervise the budget as set out in the Charte coloniale, a set of agreements enacted in $1908{ }^{19}$ The parliamentarians had approved the state's takeover of the Congo in 1908 on the premise that it would not be a burden on the national treasury. ${ }^{20}$ The colony was financed exclusively from taxes levied on firms from Belgium, most of which were partly state-owned and had been active there since the days of the Free State. One consequence of the latter's concessionary policy was the development in the Belgian Congo of a capital-intensive colonial econ-

13 Verhaegen, "Communisme," 115.

14 G. Vanthemsche, “The Belgian Colonial Empire (1885/1908-06)," in Imperien und Reiche in der Weltgeschichte. Epochenübergreifende und globalhistorische Vergleiche, eds. M. Gehler and R. Rollinger (Wiesbaden: Harrassowitz, 2014), 977.

15 M. D. Markowitz, Cross and Sword. The Political Role of Christian Missions in the Belgian Congo, 1908-1960 (Stanford: Hoover Institution Press, 1973), 21-22.

16 Vanthemsche, "Belgian Colonial Empire," 978. Of the staff of the General Government 90 percent were Catholics in the early 1950s; Markowitz, Cross and Sword, 26.

17 Vanthemsche, Belgium and the Congo, 44.

18 Markowitz, Cross and Sword, 26-28.

19 C. Young, The African Colonial State in Comparative Perspective (New Haven: Yale University Press, 1997), 161.

20 J.-L. Vellut, "Hégemonies en construction. Articulations entre État et entreprises dans le bloc colonial belge (1908-1960)," Canadian Journal of African Studies 16 (1982), 314. 
omy featuring "islands of industrialization,"21 olive and cotton plantations, copper and gold mines, as well as companies dedicated to the construction of the requisite transportation and communication infrastructure. In the southern province of Katanga, a highly profitable mining sector emerged under the aegis of the Union Minière du Haut Katanga (UMHK), ${ }^{22}$ whose high tax payments helped finance economically weaker regions.

The Belgian Congo was ruled, in a case of largely conflict-free cooperation, by a small group of officials from the Colonial Ministry in Brussels and the colonial administration, together with representatives of the Catholic missions and private companies. ${ }^{23}$ This "colonial bloc" ${ }^{24}$ also dominated the Conseil Colonial, a fourteen-member advisory body appointed by the parliament and the king and including, in addition to politicians from the Parti Catholique and Parti Libéral, missionaries, former colonial officials and business representatives from the Congo. ${ }^{25}$ This form of colonial rule lacking in political oversight was also characterized by a dearth of political participation and input within the colony itself. While the French inter-war parliament at least featured elected representatives from Senegal, ${ }^{26}$ the population in Belgian colonial territories was excluded from the political process due to their supposed immaturity and uncivilized nature. But the European inhabitants of the colony also had little political say. ${ }^{27}$ Even Belgian citizens were denied the right to vote for the duration of their stay in the Congo. ${ }^{28}$ The members of the Conseil de Gouvernement and Conseil de Province, established in 1914, which advised the colonial government on legislative matters, were not elected but appointed by the colonial government. Until the end of the Second World War these bodies were the preserve of colonial officials. The small number of Europeans in the Congo stood at just under 7,000 in 1920 and did not exceed 25,000 individuals by the end of the Second World War. ${ }^{29}$ Of the 33,787 Europeans living in the Congo in 1946, 70 percent came from Belgium, half of them women and children. The 16,708 European men consisted of 3,287 colonial officials, 1,996 missionaries, 8,683 white-collar workers in

21 Seibert, Globale Wirtschaft, 178.

22 Ibid., 117-118.

23 Vanthemsche, "Belgian Colonial Empire,” 977.

24 Vellut, "Hégémonies."

25 Young, Politics, 24-25.

26 Cooper, Citizenship, 6-7.

27 R. von Albertini, Dekolonisation. Die Diskussion über Verwaltung und Zukunft der Kolonien 1919-1960 (Cologne: Westdeutscher Verlag, 1966), 573-574.

28 See B. Rubbers, Faire fortune en Afrique. Anthropologie des derniers colons du Katanga (Paris: Karthala, 2009), 227.

29 Young, Politics, 28; Vanthemsche, "Belgian Colonial Empire,” 978. 
businesses and merchants, and 2,772 settlers, including immigrants active in the retail trade and in skilled crafts and trades, particularly from Greece, Switzerland and Scandinavia. ${ }^{30}$ The European population was concentrated in Léopoldville and those provinces with major industries. The first calls for political participation came in the 1920s in the Katanga province, which had formerly enjoyed an administrative status independent of the General Government. ${ }^{31}$ The self-confidence of the Europeans in this economically strong centre of the copper industry was bolstered by the increasing power of the settlers in the British territories of Rhodesia and South Africa, which bordered the colony to the south. ${ }^{32}$ Many of those living in Elisabethville, the provincial capital of Katanga and the headquarters of the UMHK, maintained close links with the settler colonies of southern Africa. A large number of Britons were resident in the city, while railway lines led to Northern Rhodesia and to the coast of the Portuguese colony of Angola. The colonial capital of Léopoldville, meanwhile, seemed far away. The fact that the latter was the seat of government while the Belgian Congo was largely financed by the province of Katanga was a source of resentment and stoked desires for greater autonomy. But the settlers' demands fell on deaf ears in Brussels. ${ }^{33}$

Belgian colonial policy envisaged the granting of direct political participation to Europeans only when Congolese were endowed with the same privilege, but the latter were regarded as woefully lacking in the requisite civilizational maturity. This political disenfranchisement of the colonial society was rooted in the pronounced paternalism of Belgian colonial rule. In the early 1930s, leading Belgian colonial politician and Governor General Pierre Ryckmans justified colonial conquest with reference to the "to rule is to serve" doctrine: "To serve Africa is to civilize it [...] until the work is done and [foreign] dominion is no longer necessary." 34 The architects of Belgian colonial policy, for power-political reasons, were keen on a protracted process of civilizational maturing: they were in no rush to recognize the colonial society as politically mature. This is especially evident in the education system, which pursued the gradual development of the Af-

30 "Rapport de l'Administration de la Colonie et du Congo Belge pendant les années 1945-1946 présenté aux Chambres Législatives,” quoted in De Schrevel, Forces politiques, 52. There are differences between the population statistics produced by various state authorities. The annual statistics for 1945, for example, give a figure of 36,808 Europeans, 3,837 of them missionaries; G. Vanthemsche, La Belgique et le Congo (Brussels: Parole Silence, 2007), 404.

31 Lemarchand, Political, 60.

32 Ibid., 81.

33 Young, Politics, 45.

34 P. Ryckmans, Dominer pour servir (Brussels: Éditions universelles, 1948), 6-7. 
rican population as a whole..$^{35}$ Leopold II had already granted responsibility for education to Catholic missionary orders of Belgian provenance, thus attaining the political goodwill of the governing Parti Catholique vis-à-vis his Free State. With its commitment to the Belgian annexation of the Free State and its later takeover of the Colonial Ministry, henceforth the Parti Catholique secured a vast and exclusive sphere of activity for the missionary movement, which had been gaining in strength since the $1860 \mathrm{~s}^{36}$ Whereas in the British colonies mission schools were tasked with implementing programmes of public education, the Belgian authorities gave the predominantly Catholic missionaries free rein. ${ }^{37}$ Though Liberals and Catholics had traded fire over the Catholic Church's leading role in education in the Belgium of the $1880 \mathrm{~s},{ }^{38}$ even anticlerical representatives of the Parti Libéral accepted the missions' monopoly in colonial schooling. ${ }^{39}$ When it came to the affairs of the Congolese population, the Parti Libéral largely failed to live up to its name, putting its faith in the mission schools' educational and moral competence to furnish the colonial economy with capable workers. ${ }^{40}$ The party viewed Catholicism as a social binding agent and aid to political stabilization, akin to its role in Belgian history. With its linguistic bipolarity reflecting its Walloon and Flemish communities, the country's foundation and unification had rested on the shared Catholic faith, in addition to a strong national bourgeoisie. ${ }^{41}$ By favouring Catholic orders from Belgium, which were the near-exclusive recipients of state subsidies after $1908,{ }^{42}$ the Belgian political establishment aimed to give the civilizing mission in the Congo a national stamp. ${ }^{43}$

The Congo missions' educational assignment stood in the tradition of the Belgian school system, which had been predominantly Catholic since the midnineteenth century, ${ }^{44}$ a state of affairs that had only briefly come up for debate during the Europe-wide "culture war" of the 1880s. The miners' strikes of 1886 demonstrated to the Belgian state the importance of inculcating, through universal schooling, the next generation of the working class with bourgeois notions of

35 Young, Politics, 36-42.

36 Vanthemsche, Belgium and the Congo, 65.

37 Stengers, Congo, 205-220.

38 Vanthemsche, Belgium and the Congo, 34.

39 Markowitz, Cross and Sword, 21-22.

40 Ibid., 12.

41 Conway, Sorrows, 381; M. Conway, "Belgium," in Political Catholicism in Europe, 1918-1965, eds. T. Buchanan and M. Conway (Oxford: Oxford University Press, 1996), 189.

42 Markowitz, Cross and Sword, 8.

43 Ibid., 55.

44 Stengers, Congo, 196; B. A. Cook, Belgium: A History (New York: Peter Lang, 2002), 78-79. 
morality and Catholic humility in order to curb their revolutionary potential. Through a curriculum intended to help produce compliant citizens, the political elites sought to cultivate faith in the authorities and an ascetic work ethic, while also putting a brake on the growing socialist movement. In keeping with the motto "to teach is good, to impart morality is better," ${ }^{45}$ Belgian pupils received a church-run form of teacher-centered learning whose "cult of order" ${ }^{46}$ was focused more on socialization, moralization and disciplining than on enhancing knowledge or encouraging independent thought. ${ }^{47}$ The mission schools in the Congo in particular took on the air of institutions of morality, in which children were to be shaped into obedient colonial subjects of Catholic faith who would fit neatly into the colonial order. ${ }^{48}$

The takeover of the Congo by the Belgian state led to the carefully managed expansion of the colonial education system. Education commissions were convened and these advocated continuing, and expanding on, the approach taken under the Free State. A comprehensive and mission-based programme of primary schooling in indigenous languages was to continue to ensure the moral education of the population. ${ }^{49}$ Even Louis Franck, Liberal colonial minister and well-known agnostic, was convinced that moral education must go hand in hand with evangelization. Congolese, he believed, must convert to the Catholic faith, leaving their traditional spirituality behind them, which would guarantee a higher level of morality. ${ }^{50}$ With the expansion of the educational landscape, the number of Belgian missionaries in the Congo increased dramatically. In 1908 just 335 such individuals were present in the territory, but by 1927 this figure had increased fivefold, and the latter figure had increased ten times over by

45 Article published in the Belgian press in 1899, quoted in C. Reimann, Schule für Verfassungsbürger? Die Bildungsligen und der Verfassungswandel des späten 19. Jahrhunderts in Belgien, England und Frankreich (Münster: Waxmann, 2016), 203.

46 S. Van Ruyskensvelde et al., "The Cult of Order: In Search of Underlying Patterns of the Colonial and Neo-Colonial 'Grammar of Educationalisation' in the Belgian Congo. Exported School Rituals and Routines?,” Paedagogica Historica 53 (2017).

47 M. Depaepe and K. Hulstaert, "Creating Cultural Hybridity by Exporting Metropolitan Structures and Cultures of Schooling and Educationalisation? The Emergence of a Congolese 'Elite' in the 1950s as a Starting Point for Further Research,” European Educational Research Journal 12, no. 2 (2013): 202.

48 Tshimanga, Jeunesse, 89.

49 M. Depaepe, "Sous le signe du paternalisme: les politiques éducatives au Congo belge, 1908-1960,” in L'école et la nation, eds. B. Falaize et al. (Lyon: ENS Éditions, 2010), 6.

50 Van Ruyskensvelde et al., "The Cult of Order”; Nziem, Histoire générale, 402. 
$1939 .^{51}$ In the 1930s there were more missionaries than colonial officials in the Belgian Congo.

In addition, colonial education policy was rooted in racist ideas that assumed that Africans were intellectually deficient. Senior representatives of missionary orders and the colonial administration thus categorically ruled out comprehensive teaching in French, citing this supposedly limited ability for advanced thought. ${ }^{52}$ The missionaries, most of them from rural Flanders, ${ }^{53}$ also welcomed a system of primary education in vernacular languages. They perceived the exclusive use of French by the colonial administration as an import of Belgium's national cultural and linguistic policies, which systematically suppressed the Flemish language. ${ }^{54}$ The primary educational task was to provide manually trained workers. In the trenchant words of Liberal colonial minister Franck, the goal was not "to create an imitation of Europeans, a black Belgian, but rather a better Congolese, [...] healthy and hard-working [...], aware of his obligations to his fellows and to authority." 55

In the late 1920s the Congolese educational landscape featured two years of primary education that imparted basic knowledge of arithmetic, writing and reading in vernacular languages, hygiene regulations, obedience to authority, and the Catholic faith. A small fraction of primary school children were girls, and even in 1960 they made up less than 20 percent, ${ }^{56}$ so that the Belgian Congo placed last when it came to the literacy of women in colonial Africa. Most pupils were boys, who were also trained in basic manual work. Yet, the first stage of primary education was marked by a high degree of social penetration, encompassing one in ten children in 1926, one in four in 1932 and half of all children in 1946.

A second stage of primary education was provided by the larger mission stations and institutions established in urban settlements for a small group of the best pupils. By 1933, this group comprised no more than 10 percent of children enrolled in primary school, a figure that had risen to one in five 10 years later. ${ }^{57}$

51 Vanthemsche, La Belgique et le Congo, 404.

52 Tshimanga, Jeunesse, 85.

53 Eight out of ten missionaries were from Flanders in 1948. Vanthemsche, Belgium and the Congo, 63.

54 Stengers, Congo, 218. On the position of the Flemish language in Belgium's development as a nation, see Cook, Belgium, $80-84$.

55 L. Franck, Le Congo belge (Brussels: La Renaissance du livre, 1930), 282.

56 B. Yates, "Church, State and Education in Belgian Congo," in Women's Education in the Third World: Comparative Perspectives, eds. G. P. Kelly and C. M. Elliott (Albany: Suny Press, 1983), 143. 57 Tshimanga, Jeunesse, 89. 
This stage of education lasted for another three years and was divided by gender. The curriculum for boys focused on deepening manual skills and included additional subjects such as history and geography and, for the first time, French, which was compulsory in the cities and optional in the rural areas. This educational stage prepared pupils for life in a colonial working world and imparted a new gendered order: while boys' schools trained their pupils for agricultural and artisanal wage labour and for secondary schools, the girls' schools prepared their charges for the roles of mother and housewife, with lessons in sewing, handicrafts and childcare. The Catholic mission schools propagated the concept of monogamous and patriarchal nuclear families featuring a bourgeois division of labour and domesticity. This gendered order was in part an attempt to counter the polygamy dominant throughout the Congo, which the missionaries regarded as a sign of a lack of civilization and heathenism. Furthermore, women were to be ousted from their traditional agricultural activities, ${ }^{58}$ conventionally regarded as unmasculine, ${ }^{59}$ in favour of male wage labourers. A vanishingly small proportion of the female population attended those educational institutions that went beyond the primary level and that helped cement the new gender relations. There girls either learned to grow vegetables and medicinal plants for domestic use or were trained to work as primary school teachers or assistants to European social workers who provided housekeeping courses for married Congolese women. ${ }^{60}$

But even the secondary school syllabus for the male population was very limited and reflected the colonial administration's and companies' demand for qualified personnel. Here one in a hundred schoolchildren were trained as intermediaries for the colony.$^{61}$ The écoles moyennes produced secretarial assistants, who were trained, in French, in bookkeeping and typewriting. The largest group - between 54 percent and 74 percent - was made up of pupils attending the écoles normales, which met the growing need for primary school teachers, taught the requisite know-how but were not intellectually stimulating. The specialized écoles professionelles chiefly produced workers such as carpenters, farmers and masons, who were later deployed as foremen. In addition, from the mid1920s onwards a handful of schools were founded for doctor's assistants, who worked in mission-run medical centres and hospitals after three to four years of education. ${ }^{62}$ The two-tier seminaries provided the highest level of educational attainment possible, as the authorities did not envisage a university education

58 Yates, "State and Education," 130.

59 Gondola, Tropical, 12.

60 Yates, "State and Education," 137.

61 Expressed in figures: a total of 1,256 in 1929 and 3,630 in 1943. See Tshimanga, Jeunesse, 89.

62 On this paragraph, see ibid., 104-120. 
for Congolese. By 1945, a total of 1,111 Congolese had attended the six-year petit séminaire, with its focus on Latin and the humanities, while 221 had studied at the grand séminaire, with its eight-year education in philosophy and theology. The fact that only one in twelve seminary graduates entered into church service shows that Congolese wishing to obtain a higher level of education and lucrative employment sometimes feigned a desire to dedicate their lives to God. British and French colonial policy set far greater store by higher education. In the inter-war period in Dakar, Lagos, Accra and elsewhere elite educational institutions emerged that produced African cadres for colonial administration, while others studied at universities in Paris or London. Nonetheless, the rate of school enrolment in the Belgian Congo was markedly higher than in French and British Africa. In the 1930s, a figure of 15 percent in the Congo contrasted with less than 4 percent in French West Africa. ${ }^{63}$ The British Gold Coast did not reach this level until the late 1940s. ${ }^{64}$ Hence upon independence the Belgian Congo was the African country with the greatest number of primary school children and priests, making up a third of the clergy of the entire continent. Yet it also had the smallest number of university graduates. Upon independence, fifteen Congolese were studying in Belgium, while another thirty had a degree awarded by one of the two universities in the Belgian Congo, which opened their doors in the mid1950s. ${ }^{65}$

The conscious decision to forego the development of an educated intellectual elite was rooted in a fear Belgium shared with other European colonial states, namely that the members of such an elite might be in a position to manipulate an African society they now felt alienated from and to disseminate anticolonial ideas. In the 1920s Belgian politicians dedicated to colonial policy in the Parti Catholique and Parti Libéral felt that the politicization of intellectuals in the British and French empires had borne out their fears that this group might be susceptible to pan-Africanist and communist ideologies. ${ }^{66}$ As they saw it, to educate Africans was to risk deforming and miseducating them. The mission-run further education of several Congolese intermediaries for subordinate positions within the colonial administration, companies and schools, meanwhile, was accepted as a "necessary evil."67

63 J. Osterhammel, Kolonialismus. Geschichte - Formen - Folgen (Munich: C. H. Beck, 1997), 107. 64 See B. G. George, Education in Ghana (Washington: ERIC Clearinghouse, 1976), 208.

65 Young, Politics, 200 and 280.

66 Stengers, Congo, 216; Tshimanga, Jeunesse, 69.

67 D. Dibwe dia Mwenbu, "La formation des élites coloniales. Le cas de la province Katanga," in Le manifeste "Conscience africaine” (1956). Élites congolaises et sociétés coloniales. Regards croisées, ed. N. Tousignant (Brussels: Presses de l’Université Saint-Louis, 2009), 118. 


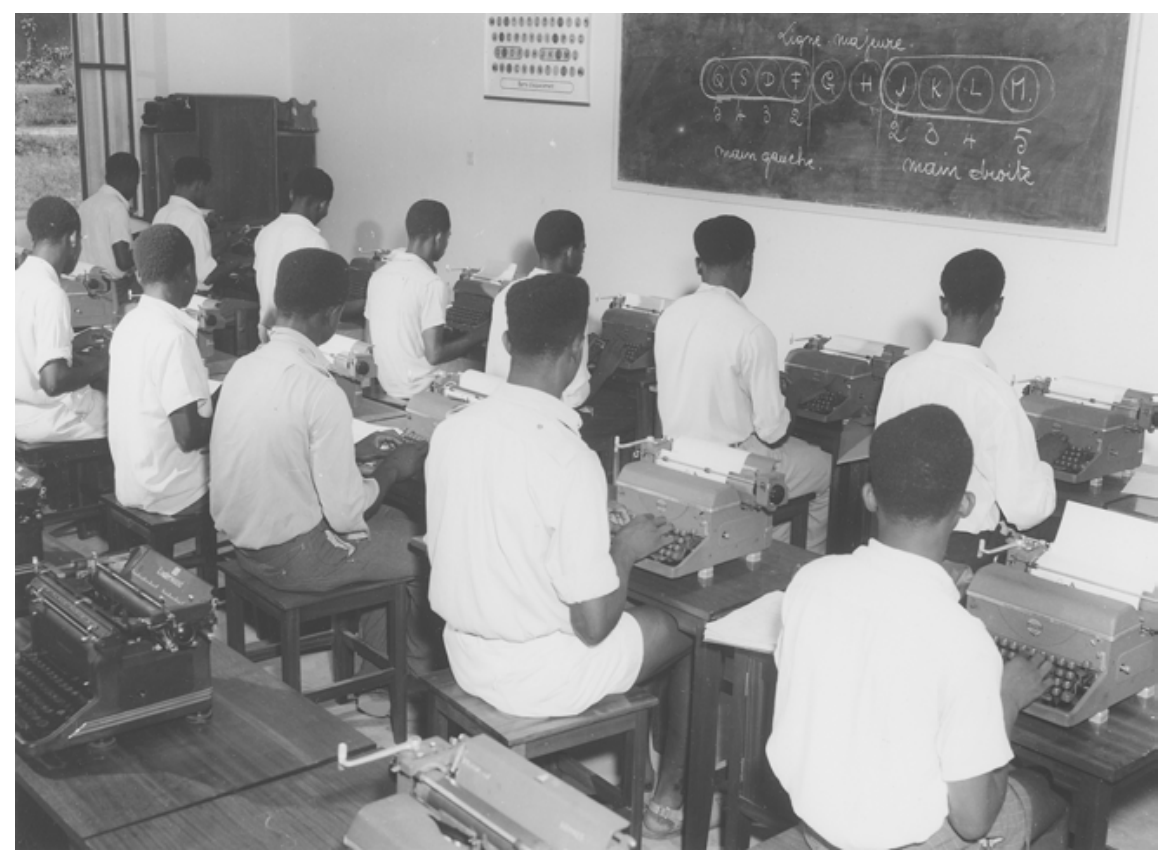

Fig. 3: Pupils at the école moyenne in Coquilhatville.

In the inter-war period, the combination of comprehensive primary education and a very limited form of secondary education was paralleled by a debate on the ramifications, and desired scope, of the associated transformation of African society. In general terms the European colonial powers questioned how far their alleged civilizing mission ought to go. ${ }^{68}$ We can discern two ideal-typical schools of thought here. The ideology dominant among missionaries and colonial officials assumed the primacy and superiority of European civilization: Africans must compensate for their backwardness through cultural assimilation. After the First World War an indigenist strand of thought argued against this postulate of assimilation and called for greater efforts to preserve indigenous institutions and ways of life. The method of indirect rule, introduced around the same time in British colonial territories, reflects the prominence of this phenomenon in the inter-war period. Supporters of both ideologies were to be found among the Belgian missionary orders as well as among politicians dedicated to colonial policy. A modus vivendi took hold that propagated a form of selective adaptation. The idea here was that African culture contained elements worth preserving but

68 Eckert, "Kolonialismus, Moderne," 64-65. 
also those that must be supplanted by a Catholic-bourgeois value system. Polygamy was the most significant example of a feature that Belgian missionaries sought to combat as un-Christian and uncivilized. In practice, the thesis of adaptation proved to be a malleable and contradictory form of the postulate of assimilation: the more educated Congolese were, the more vehement the calls for cultural adaptation to Christian-bourgeois moral notions became, while the shift away from the traditional milieu was lamented ever more vociferously.

The missionaries, of course, tended to discern threats to Congolese society in the way people lived outside of school rather than in their own evangelization and schooling. They were particularly concerned about Congolese in the cities, home not just to ordinary workers but also to many graduates of post-primary schools who found work in the administrative system and companies. ${ }^{69}$ Between 1924 and 1929, the population of Léopoldville alone doubled as a result of the inflow of workers, to 46,000. Large companies had established branches there, including palm oil producers from Belgium and Great Britain, textile and drinks factories, as well as private and state-run transportation companies. The highly regarded missionary Joseph Van Wing assailed the miserable living conditions in the overcrowded, unsanitary districts, where Africans lived in jerry-built structures. ${ }^{70}$ For Van Wing, who was in charge of a number of Jesuit mission schools in the vicinity of Kinshasa, the cities were sites of deracination where neither the instruments of missionary civilizing nor traditional rules held sway. ${ }^{71}$ Four times as many Congolese men as women lived there. Only officially married women were granted residence, while their unmarried counterparts had to pay a substantial penalty tax. Despite this, as described by Van Wing, 93 percent of the women in Léopoldville were unmarried, and prostitution was widespread. ${ }^{72}$ The missionaries' complaints about moral degradation and concerns about political unrest in the cities were echoed by the colonial officials. Over the course of the 1920s, these anxieties led to the missions' first attempts to achieve the extramural moralization and socialization of urban and educated Congolese. To understand this project, we must look at the social order in the metropole.

Since the late nineteenth century, Belgium's "patchwork society" had been based on the coexistence of social associations that reflected political and ideological conflicts and that organized social milieus on the basis of age, gender,

69 Markowitz, Cross and Sword, 16-17.

70 Gondola, Tropical, 38-39.

71 Markowitz, Cross and Sword, 17. For Van Wing’s biography, see J. Denis, “J. Van Wing," in Biographie Belge d'Outre-Mer, vol. VIII, ed. Académie Royale des Sciences d'Outre-Mer (Brussels: Librairie Falk fils, 1998).

72 Gondola, Tropical, 90. 
language, religion and social status. ${ }^{73}$ The various so-called pillars consisted of interconnected organizations that were grouped around political parties and included trades unions, media, educational establishments, social insurance institutes and cultural associations. The most influential pillars with the greatest number of members were affiliated with the Parti Catholique and the BOP, while those associated with the Parti Libéral and the Flemish movement were less prominent. These pillars underlay the firmament of the Belgian state and established national unity amid social diversity. The political elites negotiated conflicts and sought compromises in close coordination with these pillared parallel societies. ${ }^{74}$ The Parti Catholique had responded to the emergence of the BOP, founded in 1885, by erecting an extensive religious pillar: henceforth, the former party tried to defuse the "social question" thrown up by industrialization and proletarianization by means of catholic trades unions and co-operatives, as well as health insurance schemes. ${ }^{75}$ Prior to the First World War, 40 percent of trades union members belonged to one of the Christian trades unions. ${ }^{76}$ With their paternalistic clubs and societies, services for families, and recreational activities organized with the help of sporting and continuing education associations, the Parti Catholique and Parti Libéral sought to achieve the "moralization of the worker."77 The imparting of "good manners" and familial models that were styled bourgeois or Catholic depending on one's political views, ${ }^{78}$ and the concurrent improvement of Belgians' material lot, were attempts to stabilize the social and political order.

Given the consensus within the Belgian political class on the need to keep the Congo out of politics, there was no prospect that this pillarization, closely associated with the political parties, or the extramural moralization of Belgian society, would be transferred wholesale to the colonial context. Nonetheless, the colonial state and the missionaries recognized in this pillar-like structure useful building blocks for the construction of a milieu of educated Congolese. The Colonial Ministry thus granted the Belgian missions a monopoly of extramu-

73 Conway, Sorrows, 285.

74 D. Laqua, The Age of Internationalism and Belgium, 1880-1930. Peace, Progress and Prestige (Manchester: Manchester University Press, 2013), 84.

75 See P. Delwit and B. Hellings, "Du parti catholique au Centre démocrate humaniste. Les questionnements de la démocratie chrétienne en Belgique francophone," in L'année sociale 2002, ed. S. Béroud (Brussels: Éditions Syllepse, 2003).

76 Laqua, Age of Internationalism, 83.

77 J. Puissant, "Le bon ouvrier, mythe ou réalité du XIXe siècle. De l'utilité d'une biographie. J. F. J. Dauby (1824-1899),” Revue belge de philologie et d'histoire 56 (1979), 880.

78 T. Van Osselaer, The Pious Sex. Catholic Constructions of Masculinity and Femininity in Belgium, 1800-1940 (Leuven: Leuven University Press, 2014), 78-80. 
ral education as well, extending the Catholic movement, which was growing in strength in inter-war Belgium, to the colonial society.

Catholic Action was a movement proclaimed by Pope Pius XI in Europe after the First World War. It saw itself as a response to secularization, urbanization and social differentiation, which the Catholic Church perceived as a threat to its social hegemony. ${ }^{79}$ In addition to the clergy, the Pope now urged the laity to play their part in the "Christianization of the world" and to join the battle against the "excesses of modern laicism." ${ }^{80}$ Catholic Action spread from Italy across Western Europe and encompassed publishers, modern media and mass movements. In the 1920s it focused on recreational organizations for young people and, when the first generation had reached maturity, for adults as well. In much the same way as the established pillars of Belgian society, Catholic Action was split into subgroupings that divided labourers from peasants, men from women, boys from girls and Walloons from Flemings. ${ }^{81}$ The apolitical character of Catholic Action, a result of its establishment in fascist Italy under Mussolini, prompted its members to turn their backs on political activities. This undermined the unity of the Catholic associational landscape, while the movement also brought together anti-parliamentary currents that at times accused the governing Parti Catholique of being overly liberal. ${ }^{82}$

This distance from the political parties, however, enabled Catholic Action to expand to the Belgian Congo. There the missionaries emulated the approach of Jeunesse ouvrière chrétienne (JOC), which had been founded in Brussels in 1925 and was growing into a global organization. Its informing conviction was that there was a vital need to stop relying on men of the church to attend to the working class. Instead believing workers must be won over at a young age so that they might impart Christian values and a moral way of life within their own milieu. ${ }^{83}$ Likewise, from now on the apostles to the Congolese were to be Congolese themselves. In keeping with missionaries' complaints about the immoral conduct of educated city dwellers, missionaries - especially those in charge of secondary schools - answered the Pope's call for Catholic action. Against the background

79 On the Catholic mission, see K. Große Kracht, "Missionsland Europa. Katholische Aktion und 'missionarische Bewegung' im französischen und deutschen Katholizismus der 1940er Jahre,” Themenportal Europäische Geschichte (2009), http://www.europa.clio-online.de/2009/Article=384 (24 September 2013).

80 Ibid., 2.

81 Van Osselaer, Pious, 181 and 380.

82 See T. Van Osselaer, "Christening Masculinity? Catholic Action and Men in Interwar Belgium," Gender \& History 21, no. 2 (2009): 382-383.

83 See Große Kracht, "Missionsland," 3. 
of "Catholic internationalism" 84 the missionaries acted on their own initiative and independent of the metropolitan structure. ${ }^{85}$ In the late 1920s, the Belgian Scheut missionaries established an association in Léopoldville for former pupils of their training centre for office assistants, which soon included all graduates of the Scheut mission schools. An equivalent group was founded by the second major missionary order, the Frères des écoles chrétiennes, which was in charge, among other things, of the Colonie Scolaire at Boma in western Congo, an establishment that trained typists to meet the state's administrative needs. Both missionary orders distributed periodicals as well. In addition to religious content these provided information on individual school leavers and portrayed the "elite regiment of evangelization" as "good Christians," often pictured in suit and tie at their church weddings, with brides in white wedding dresses at their side. $^{86}$

In 1931 a branch of the JOC was established in Léopoldville as well. A missionary of the Scheut order who was familiar with the movement from Belgium and believed it vital that it expand into the Congo ${ }^{87}$ began to promote Christian monogamy among unmarried foremen, who were supposed to influence the urban workers as moral role models. ${ }^{88}$ In the late 1930s, for a short time Léopoldville was home to the JOC's first women's section under the leadership of a Catholic nun, an organization that sought to prepare women for marriage and the life of a housewife. In the industrialized region of Katanga, an independent network of paternalistic recreational institutions with similar programmes was established through close cooperation between the UMHK and the Catholic Church. Coordinated by the local apostolic vicar, these sought to attract the large number of resident Congolese wage labourers. ${ }^{89}$ At the behest of the company, which in the 1930 s was keen to achieve a stable workforce, ${ }^{90}$ the Belgian missionaries also gave lessons on the premises. ${ }^{91}$

84 V. Viaene, "Vers une histoire de l'internationalisme catholique au XIXe siècle," Schweizerische Zeitschrift für Religions- und Kulturgeschichte 100 (2006).

85 L. Van Rompaey, "The Development of the Catholic Youth Organizations in the Belgian Congo (1908-1960)," in The Colonial Experience in Education. Historical Issues and Perspectives, eds. A. Nóvoa and M. Depaepe (Gent: CSHP, 1995), 194.

86 Statements and images of this kind can be found in 1934 issues of Signum Fidei, an organ serving the graduates of the mission schools run by the Frères des écoles chrétiennes.

87 R. Pasquier, La jeunesse ouvrière chrétienne en Afrique noire (1930-1950) (Paris: Karthala, 2013), 95-96.

88 Tshimanga, Jeunesse, 145.

89 Pasquier, La jeunesse, 98.

90 Seibert, Globale Wirtschaft, 203-206.

91 Markowitz, Cross and Sword, 45. 
Initially Catholic Action targeted only an elite group that was to be encouraged to live a moral life. ${ }^{92}$ In both Belgium and in the Congo the gendered order this organization propagated was based on a patriarchal and bourgeois model that ascribed the task of evangelization to men. While men were to be active within the public sphere, women were allocated to the domestic sphere of the family and child-rearing. ${ }^{93}$ For the activists of Catholic Action, the restoration of Belgium's Catholic society and the evangelization of the colonial society both depended on ensuring the prevalence of the ideal-typical bourgeois family. ${ }^{94}$ Some militant Flemish divisions of the Belgian organization drew on the masculine ideals of an authoritarian zeitgeist, privileging the symbolism of Catholics as warriors and soldiers. This they did in significant part in order to circumvent the contemporaneous debate on religiosity as female terrain and to criticize the hegemony of the Francophone bourgeoisie within the Parti Catholique. ${ }^{95}$ Nonetheless, the ideal of the Congolese believer was essentially that of a thoroughly obedient, pious and bourgeois man, the head of a patriarchal Christian family.

In Belgium Catholic Action was dedicated to the notion of "moral rearming," through which the Catholic Church sought to counter mass culture and sexual freedoms and to shore up a patriarchal gender-based order subject to increasing challenge. ${ }^{96}$ To some extent Catholic Action was the confessional articulation of the process of "recasting bourgeois Europe"97 immediately after the First World War, when Western European governments were injecting new vigour into the conservative vision of a bourgeois society. While the metropolitan society was supposed to return to an imagined bourgeois tradition, in the Congo this valorized bourgeois way of life was associated with a vision of a future society. To the representatives of Catholic Action, the Belgian Congo appeared to be a promising field of action. In contrast to Western Europe, it was free of political conflicts, popular culture, anticlerical critics and Communist subversives. ${ }^{98}$ For these Catholic activists the small group of educated Congolese constituted the vanguard

92 Tshimanga, Jeunesse, 194.

93 Van Osselaer, “Christening," 385-386 and 391; Van Osselaer, Pious, 12-13 and 25-26; Conway, "Belgium," 190.

94 Van Osselaer, Pious, 80.

95 Van Osselaer, “Christening," 385-386.

96 M. Depaepe and K. Hulstaert, "Demythologising the Educational Past: An Attempt to Assess the Power of Education in the Congo (DRC) with a Nod to the History of Interwar Pedagogy in Catholic Flanders," Paedagogica Historica 51 (2015): 1-2 and 16-17.

97 C. S. Maier, Recasting Bourgeois Europe: Stabilization in France, Germany, and Italy in the Decade after World War I (New Jersey: Princeton University Press, 1975).

98 Depaepe and Hulstaert, "Demythologising," 16. 
and apostles of a long-term civilizing mission that was gradually to render the ideas of the monogamy-based family, bourgeois virtues and gender roles compatible with the local society. Missionaries and politicians concerned with colonial policy shared the view that the civilizing mission was an important educational task, but it was not one that could be rushed. They were convinced that the population must be civilized steadily and very gradually, while the small number of reasonably educated Congolese must be pushed, under strict observation, to achieve a higher degree of assimilation.

\section{Second World War, second colonization}

During the Second World War several actors began to call for the reform of Belgium's colonial policy, questioning the legitimacy of its paternalistic attitude, tentative fostering of a Congolese elite, "depoliticization of colonial policy" 9 and efforts to seal the colony off from the rest of the world. The Second World War heralded the start of contradictory processes in colonial Africa. First, it made Africa far more important to the European colonial powers. While Great Britain could rely on the material and human resources of its entire empire, initially only French Equatorial Africa sided with the exile government under General Charles de Gaulle in London. The Allied invasion of southern Europe, however, was launched from French colonial territory, the Vichy regime having lost control of the country's African colonies in late 1942. Second, the world war induced international power shifts and triggered the emergence of new institutional frameworks, so that the European colonial powers felt compelled to carry out reforms and relaunch their colonial rule. Furthermore, the atrocities carried out by Nazi Germany and its subjugation of eastern Europe had discredited attempts to legitimize colonial rule based on race. ${ }^{100}$ Other important developments were the rise of the United States to the status of world power and its government's increasingly critical stance towards colonialism, which had already found expression in the Atlantic Charter of August 1941; this affirmed the right of every people to elect its own government. Initially, however, the Charter was no more than rhetoric: "A policy of decolonization and coalition warfare were scarcely compatible."101 This changed in June 1945 with the founding of the United Nations (UN), the direct heir to the League of Nations institutionally though

99 Albertini, Dekolonisation, 575.

100 Marx, Geschichte Afrikas, 247-253.

101 Eckert, Herrschen, 5. 
not ideologically. While the latter body still recognized Europe's tutelage of the colonized parts of the world, paternalism now gave way to an agenda of emancipation, on which both the United States and the Soviet Union, along with the Eastern Bloc countries, insisted. ${ }^{102}$ That the UN Charter by no means spelt the end of colonialism but merely ushered in its reform was due to a change of attitude on the part of the United States. Under its new president Harry S. Truman, the brewing confrontation with the USSR and the communist system prompted the United States to prioritize security policy over the freedom of peoples. ${ }^{103}$ In the Charter independence became a mere slogan open to broad interpretation. In their trust territories and colonies, the colonial powers were supposed to lay the ground for self-government, which granted the vernacular population a political say but left colonial rule in place. ${ }^{104}$ While the colonial states had no need to fear any interference in their sovereignty, henceforth they did have to report on their colonies' development to the specially created United Nations Trusteeship Council. ${ }^{105}$ The yardstick here was provided by the commitments set out in Article 73 of the Charter: to advance the inhabitants' wellbeing, to foster social, economic and educational progress, and to promote self-government "according to the particular circumstances of each territory and its peoples and their varying stages of advancement."106

While the European colonial powers now had to report back to the United Nations with updates on their colonial possessions, Great Britain and France were by no means minded to withdraw from Africa. Rather than decolonization, what they had in mind was "recolonization." Hence, before the war was over both imperial powers had announced far-reaching reforms based on the notion of "developing" their colonies: through state investment in modernization projects along with the introduction of the kind of welfare and social security programmes that had long since been established in the Western European mother countries. ${ }^{107}$ Plans of this kind had certainly crossed the desks of the various co-

102 Ibid., 4.

103 G. Th. Mollin, USA und der Kolonialismus. Amerika als Partner und Nachfolger der belgischen Macht in Afrika, 1939-1965 (Berlin: De Gruyter, 1996), 136.

104 On the influence of the British Colonial Office on the paragraphs concerning colonial rule in the UN Charter, see W. R. Louis, Ends of British Imperialism: The Scramble for Empire, Suez, and Decolonization (New York: I. B. Tauris, 2006), 691-692.

105 The following marks draw on Mollin, USA und der Kolonialismus, 143, 189 and 192-193. See also Vanthemsche, Belgium and the Congo, 135-140.

106 Charter of the United Nations, Chapter XI: Declaration regarding non-self-governing territories, Article 73.

107 For an introduction to this topic, see A. Eckert, Exportschlager Wohlfahrtsstaat? Europäische Sozialstaatlichkeit und Kolonialismus in Afrika nach dem Zweiten Weltkrieg (Bochum: Stif- 
lonial ministries in the inter-war period. But they had rejected the idea of putting them into practice out of fear of the consequences of the associated processes of social transformation and in light of the premise that the colonial possessions must be financially self-supporting. ${ }^{108}$ The post-war order and the pressure to lend new legitimacy to colonial rule brought these plans back onto the agenda. The so-called "second colonization of Africa"109 encompassed a range of measures centred on programmes of state investment, along with social, economic and administrative reforms - a colonial policy that was not geared exclusively to advancing the metropole's economic interests but towards the needs of Africans as well. This socioeconomic approach was complemented by new and expanded opportunities for political participation within colonial society. ${ }^{110}$ Developmental colonialism was supposed to help the population achieve "political maturity" and thus lay the foundation stones for independence. ${ }^{111}$ Great Britain, for example, passed the Colonial Development and Welfare Act in 1940 and sought to introduce the first forms of self-government in its African colonies after 1945. ${ }^{112}$ From 1946, in the shape of the Fonds pour l'investissement en développement économique et social, France transferred funds from the metropole to the colonies to expand infrastructure and advance the welfare of the vernacular population. ${ }^{113}$ And in 1944, while France was still under German occupation, at the Brazzaville Conference in French Equatorial Africa, which remained loyal to the exile government, General Charles de Gaulle announced his intention to integrate representatives of the African elite into the political structures of the metropole and to raise the living standards of France's colonial subjects. ${ }^{114}$ The Union Française, which began to take shape over the next few years, promised

tung Bibliothek des Ruhrgebiets, 2007), 8; A. Eckert, "Wohlfahrtsmix, Sozialpolitik und 'Entwicklung' in Afrika im 20. Jahrhundert," in Sozialpolitik in der Peripherie. Entwicklungsmuster und Wandel in Lateinamerika, Afrika, Asien und Osteuropa, eds. J. Jäger et al. (Vienna: Südwind, 2001), 100-101 and 106-107. For a programmatic account, see Cooper, Decolonization, 16.

108 On the British colonies, see Eckert, Herrschen, 101. On the French colonies, see Cooper, Decolonization, 176.

109 M. Crowder, "The Second World War: Prelude to Decolonisation in Africa," in The Cambridge History of Africa, vol. 8 c, 1940-1975, ed. M. Crowder (Cambridge: Cambridge University Press, 1984), 28. This term has become a standard feature of overviews of colonialism after 1945. Osterhammel, Kolonialismus, 45. "Second colonial occupation” is the phrase used for Britain's Africa policy after 1940 in Eckert, Herrschen, 97.

110 Osterhammel and Jansen, Dekolonisation, 41.

111 Eckert, "Spätkoloniale Herrschaft," 6.

112 For detailed information, see Eckert, Herrschen, 103-110.

113 Cooper, Decolonization, 176.

114 Ibid., $176-182$. 
the inhabitants of the colonies, above all the évolués, that the Republican pledge of equality would be put into practice. De Gaulle's speech, in particular, conveyed to the Belgian colonial government across the Congo River the pressing need to take action.

Belgium certainly adopted elements of the French and British reforms but pursued continuity in its colonial policy and thus an apolitical form of colonial development. Through a tentative programme of reforms, politicians dedicated to colonial policy sought to ease internal conflicts and external tensions that had come to light during the war. When the war began it had initially been unclear whether the Belgian Congo would fall into the hands of the Allies or the Axis powers. ${ }^{115}$ This was by no means a minor issue as the colony was of strategic importance to the war as one of the largest producers of raw materials, such as copper, in the world. As a result of the German occupation the Belgian government had gone into exile, but the king refused to stand shoulder to shoulder with Great Britain and France and remained in the country, intending to install a collaborationist regime. Only when representatives of Belgium's exile government had assured the Allies of access to the Congo's economic resources as a contribution to the war effort and the colonial minister had set up shop in London did Great Britain drop its plans to treat Congo as an independent state if necessary. That the Allies could count on the cooperation of the Belgian Congo was partly due to the strong position of Governor General Pierre Ryckmans, a Catholic jurist from Antwerp, who had been in office since the 1930s. ${ }^{116}$ Contra the demands issuing from the European colonial population for loyalty to the Belgian king and strict neutrality, he argued in favour of supporting the war against Germany. Congo's military contribution, which saw the deployment of Belgian colonial troops of the Force Publique in Africa and Asia, remained marginal. But the production and export of rubber, palm oil and copper, which increased many times over, were important to the Allied war economy. The rare uranium used in the US-American nuclear bombs dropped on Hiroshima also came from the Belgian Congo. ${ }^{117}$ Despite the colony's strategic role in the Allied war economy the relationship between Belgium and the United States was strained. The latter doubted that Belgian colonial policy was capable of reform and criticized the paternalism that it regarded as a key reason for the glaring neglect of the Congolese populace's cultural and political development. ${ }^{118}$

115 This section draws on Vanthemsche, La Belgique et le Congo, 174-180.

116 On Ryckmans's biography, see J. Vandelinden, Pierre Ryckmans. 1891-1959. Coloniser dans l'honneur (Brussels: De Boeck Université, 1994).

117 See Mollin, USA und der Kolonialismus, 52-87.

118 Vanthemsche, Belgium and the Congo, 135-140. 
The future of the Belgian Congo was an issue that had already worried the colonial minister and the General Government during the Second World War. Unsurprisingly, in view of the impediments to communication between London and Léopoldville and the strengthened position of the governor general, the blueprint for a reformed colonial policy came from the colonial capital. During the war it became clear that Governor General Pierre Ryckmans was convinced of the reciprocal effects of state investment programmes and socioeconomic development. The first colonial minister of the post-war period, Edgar de Bruyne of the Parti Catholique, then announced a "great plan" for the economy and for the vernacular population to share in "Congolese riches." 119 He, however, held the position for just four months; in June 1945, the Parti Catholique found itself on the opposition benches for the first time in 60 years.

The Colonial Ministry went to the Parti Libéral, with Robert Godding appointed to the post of colonial minister. He was the only Belgian parliamentarian to have spent the war years in Léopoldville and as a close confidant of Governor General Ryckmans he had helped fine-tune the plans for post-war Congo. The nephew of Liberal colonial minister Louis Franck, Godding made a name for himself early on as an expert on the Congo and had been appointed to the Conseil Colonial in 1932. ${ }^{120}$ Making reference to the UN Charter, in the shape of the Fonds du Bien-Être Indigène, Godding launched an initial development programme for the rural regions and established the Fonds d'avance to support housebuilding in Congolese urban districts. ${ }^{121}$ However, he dropped plans to implement a comprehensive and state-run development programme: as a Liberal he was generally sceptical of state intervention in the economy and instead put his faith in private enterprise in the Congo. ${ }^{122}$ Pierre Ryckmans, however, who had resigned as governor general in 1946 after 12 years in the post in order to defend Belgian colonial reforms as Belgium's envoy to the UN Trusteeship Council, continued to advocate such an investment plan. In a programmatic speech of farewell entitled "Towards the Future," 123 he called for state investment in a programme of social and economic development in order to eliminate poverty among Congolese. ${ }^{124}$ Another change of government in Belgium ended

119 G. Vanthemsche, Genèse et portée du "Plan Décennal" du Congo belge (1949-1959) (Brussels: Académie Royale Science d'Outre-Mer, 1994), 11.

120 On Godding’s biography, see E. Krings, “Robert Godding,” in Nouvelle biographie nationale, vol. 9, ed. Académie Royale (Brussels: Académie Royale, 2007).

121 G. Brausch, Belgian Administration in the Congo (London: Oxford University Press, 1961), 66.

122 Vanthemsche, Genèse et portée, 11.

123 This is also the title of the Belgian Congo's official anthem.

124 Vanthemsche, Genèse et portée, 9. 
Godding's period in office after two years in March 1947. The Colonial Ministry was handed back to the Parti Catholique, which had reinvented itself in the interim, to cross-confessional intent, as the Parti Social Chrétien (PSC). Colonial Minister Pierre Wigny now launched a large-scale, state-orchestrated programme intended to achieve the social and economic modernization of the colony. Charged with implementing it was Hendrik Cornelis, who had advocated pertinent reform projects during the war as a high official at the General Government's Economic Department. The so-called Ten-Year Plan was modelled on the development programmes recently launched in the French and British colonies but also on the US-American Marshall Plan for Western Europe. ${ }^{125}$ The socially responsive welfare state in the metropole was to be paralleled by the caring colonial state. ${ }^{126}$ Ryckmans saw this as the epitome of a reformed colonial project, from which both metropole and colony were to benefit: "The colonial endeavour is on the verge of its best days. [...] At the happy conclusion of our efforts there will be a civilized Congo developed to its own benefit, a more productive supplier to the motherland, a richer customer, an even more loyal child, the best-run colony in the world." 127

In socioeconomic terms, through the Ten-Year Plan the Belgian Congo sought to emulate the developmental colonialism of the major colonial powers. ${ }^{128}$ In contrast to Great Britain and France, which financed their development programmes in Africa with public funds from the metropole, the Belgian government issued loans out of the colony's budget, ${ }^{129}$ which grew eleven times over in the first post-war decade as a result of the rise in commodity prices on the world market. ${ }^{130}$ Under the governing coalition of the PSC and Parti Socialiste Belge (PSB), which had emerged out of the BOP during the war, the Ten-Year Plan came into force in 1949 with the primary objective of enhancing "indige-

125 Ryckmans, Dominer pour servir, 66 - 69. This section draws on the speech "Goals of Tomorrow," which Ryckmans gave in January 1948.

126 On the role of the welfare state in the emergence of middle classes in post-war Europe, see B. Vogel, Die Staatsbedürftigkeit der Gesellschaft (Hamburg: Hamburger Edition, 2007); D. Hilpert, Wohlfahrtsstaat der Mittelschichten? Sozialpolitik und gesellschaftlicher Wandel in der Bundesrepublik Deutschland (1949-1975) (Göttingen: Vandenhoeck \& Ruprecht, 2012).

127 Ryckmans, quoted in Mollin, USA und der Kolonialismus, 193. The key figures informing the thinking of the UK's Labour government in 1948 also saw its colonial policy as the beginning of a new era; Eckert, Herrschen, 104.

128 Vanthemsche, Genèse et portée, 9.

129 Ibid.

130 C. Young, "Imperial Endings and Small States: Disorderly Decolonization for the Netherlands, Belgium, and Portugal," in The Ends of European Colonial empires. Cases and Comparisons, eds. M.B. Jéronimo and A.C. Pinto (London: Palgrave Macmillan, 2015), 109. 
nous welfare." ${ }^{131}$ Colonial Minister Pierre Wigny maintained the paternalistic belief that he knew what was best for the Congolese population: "It is the state's duty to develop the indigenous society." 132 A yearly average of two and a half billion Belgian francs was made available for the Ten-Year Plan, equivalent to more than half the colony's annual budget hitherto. ${ }^{133}$ One in two francs was spent on developing transport routes, while just under a quarter of the Ten-Year Plan budget was used to benefit Congolese, which meant training skilled workers, improving health care, living conditions and water supply, providing sanitation and building educational establishments. ${ }^{134}$ Wigny saw the economic plan as a means of stabilizing colonial rule and as "the best way of ensuring the amity of the population over the long-term." 135 At the same time the Ten-Year Plan served as proof of the reformability of the Belgian colonial project vis-à-vis the international community. In addition, as Belgian historian Guy Vanthemsche argues, Belgium's colonial policy was informed by the hope that economic modernization would allow the country to avoid the agitation for political independence seen in other colonial territories in Africa. ${ }^{136}$

The question of the Belgian Congo's political development had certainly been debated during the war, as a result, once again, of the demands for autonomy issuing from the European population in the southern provinces. In Léopoldville this prompted Robert Godding to call for Belgians to be included in a legislative colonial council that would enjoy executive powers. The colonial minister in London, however, was a staunch opponent of political participation for the settlers. ${ }^{137}$ After the war Governor General Ryckmans and Colonial Minister De Bruyne agreed not to implement an electoral system for Europeans. Instead, in July 1945 reforms were made to the existing consultative organs, the Conseil de Gouvernement and Conseil de Province: from now on representatives of the European population were to be appointed to these bodies in addition to colonial officials. In these forums Europeans were also responsible for African affairs; the first Congolese to be integrated into them, in 1947, were a priest and an elder who had not mastered the French language. ${ }^{138}$ Even as colonial minister Robert Godd-

131 Vanthemsche, Genèse et portée, 16.

132 Ibid.

133 Vanthemsche, Genèse et portée, 37.

134 Ibid., 34-38. See Mutamba-Makombo, Du Congo belge, 69; Mollin.

135 Pierre Wigny, quoted in Vanthemsche, Genèse et portée, 32.

136 Vanthemsche, La Belgique et le Congo, 144.

137 J. Brassinne de la Buissière and G.-H. Dumont, "Les autorités belges et la décolonisation du Congo,” Courrier hebdomadaire du CRISP 18 (2010): 11.

138 Young, Politics, 28. 
ing was open to the possibility of political decentralization. But under Christian Social leadership, from 1947 on Brussels categorically opposed the settlers' pursuit of autonomy, which had recently culminated in an apartheid state in South Africa. ${ }^{139}$

However, it was the delayed political participation of the Congolese population rather than the failure to politically integrate the white settlers that Belgium had to explain to the UN Trusteeship Council. At the United Nations Belgium presented itself as an unyielding colonial power. Former Governor General Pierre Ryckmans saw no contradiction between Belgian colonial policy and the new paradigm of colonial development. Very much in line with the international debate after 1945, he interpreted the issue of political participation for Africans as centered on the appropriate pace of decolonization, which must be geared towards colonial subjects' level of development in different areas. Ryckmans extolled the total emancipation of the Congolese people as the final, crowning achievement of colonialism. Certainly, they must be allowed to take control of their own affairs as soon as possible. But for Ryckmans the Congolese lacked the requisite political maturity. He asked the critical United States to show greater understanding for the special situation in the Congo. The territory could not, he asserted, be compared with the state of the Philippines when the United States took over from Spain as colonial rulers, as the latter had already civilized the population. ${ }^{140}$ Ryckmans saw the United States' attitude as based on ignorance of the "profound state of savagery in which we found Africa."141 Central Africa, Ryckmans contended, could not skip any developmental stages. ${ }^{142}$ Even reform-oriented circles within British Africa policy sympathized with this perspective. They declared their central and east African territories unready for the kind of self-government that had already been introduced in Ghana and Nigeria. ${ }^{143}$ In the debate on French post-war policy too, the proponents of an inclusive Union Française first had to prevail over those who insisted upon regionally variable civilizational levels among the vernacular population and who, once again, placed central Africa at the lower end of the scale. ${ }^{144}$ Apologists for Belgian colonialism began to acquire a liking for the UN Charter with its nebulous pronouncements on the advancement of colonial subjects as appropriate to their stage of development.

139 Vanthemsche, Belgium and the Congo, 82-83.

140 Ryckmans, Dominer pour servir, 54.

141 Ibid.

142 Ibid.

143 Eckert, Herrschen, 106.

144 Cooper, Citizenship, 41. 
Despite pressure from the international community the Ten-Year Plan had explicitly ruled out the political education of the colonial population. Colonial Minister Pierre Wigny declared to the Belgian parliament that "it would be absurd to try to set out in detail the development of the indigenous population's political institutions for the next ten years today." ${ }^{145}$ The cross-party consensus in Belgium that Congolese ought to be excluded from political decision-making remained in place. While the labour government that took office in Great Britain in 1945 launched an ambitious programme to ensure the indigenous community's gradual participation in local elections and municipal self-government, ${ }^{146}$ the PSB showed no comparable desire for reform despite forming part of the government. In the Conseil Colonial, where the party gained representation for the first time in 1945, it made no particular effort to emphasize the issue. ${ }^{147}$ Even the PCB, which was part of the coalition government for two years immediately after the war, dropped its anticolonial stance in favour of a reformist one and joined the other parties in singing the praises of Belgium's colonial mission. ${ }^{148}$ While the Parti Catholique, to which the Colonial Ministry had traditionally been entrusted, had set up a working group on the Belgian Congo immediately after its re-foundation as the PSC in order to debate the future relationship between metropole and colony, it was not until the early 1950s that it presented its first findings. ${ }^{149}$

Following Godding's two years in office as Liberal colonial minister, the PSC was once again in charge of colonial policy for several years and took office alone in 1950, re-establishing the old pre-war balance of power. Historian Martin Conway's observation that the PSC's assumption of power concluded a turbulent four-year post-war period, culminating in the restoration of a slightly modified social and political order, can be extended to colonial policy: ${ }^{150}$ power remained centralized in Brussels, where a small group centred on the PSC made the key decisions. Parliamentary debates, meanwhile, gave the strong impression that Belgium had no colony. The paternalism of colonial rule, which had attracted such international opprobrium, survived through an apolitical developmental

145 Wigny, quoted in Vanthemsche, Genèse et portée, 32.

146 Eckert, Herrschen, 106. For more information on the Fabians' role in the political paradigm shift in the British Colonial Ministry, see R. Finsterhölzl, "The spirit of true socialism. Das Fabian Colonial Bureau und die koloniale Reformpolitik im subsaharischen Afrika," ZfG 58 (2012).

147 Vanthemsche, "Belgische socialisten." In a 1946 minority government the colonial minister came from the PSB for the first time, though he was in office for just six days.

148 Verhaegen, “Communisme," 115.

149 Vanthemsche, Belgium and the Congo, 84.

150 Conway, Sorrows, 3-4. 
colonialism that Belgium confidently presented to the world, its welfarist elements and state modernization programmes in keeping with the socio-political zeitgeist after 1945. The Belgian Congo's post-war sorrows appeared to have been banished by the well-meaning Ten-Year Plan.

Yet the conviction inherent in Belgian colonial policy that it could accelerate social and economic development in the Congo while simultaneously kicking political education into the long grass proved fallacious. The discrepancy between the depoliticized developmental colonialism in the Belgian Congo and the growing political participation of Africans in British and French colonies ensured that Belgian policy was caught off-guard by the domino effect of continental decolonization. ${ }^{151}$ Ultimately, the "development" of colonial Africa turned out to mean development with unintended consequences. The rhetoric of development took on a momentum of its own and began to impact on society as soon as it went beyond the position papers and speeches of politicians concerned with colonial policy. Developmental colonialism opened a "Pandora's box" because the "shift away from order and stability" towards "development and progress" paved the way for new intermediaries. ${ }^{152}$ Henceforth, much like other colonial powers, Belgium relied on the educated African population. Yet the rhetoric of development aroused great expectations among the members of this new collaborative elite. They hoped to finally gain a hearing for their demands for better living conditions and the right to the kind of political participation found in the European metropoles. The history of Belgian developmental colonialism, then, is also a history of this new collaborative elite and their expectations of colonial reforms, an elite whose very name articulated the dynamism and the contradictions of late colonial subject formation: the évolués.

\section{Developmental elites}

The Ten-Year Plan, inspired by elements of welfarist thought, formed only part of Belgian colonial policy's response to the challenges of the post-war era. Belgian developmental colonialism featured an additional, idiosyncratic component: its attempt to create an elite through a process of moral education. This was the centrepiece of a new policy that differed from British and French colonial reforms in Africa, first, in that it provided neither for growing political involvement at the local level, as in the British case, nor for legal-political integration into imperial

151 Osterhammel and Jansen, Dekolonisation, 77.

152 Marx, Geschichte Afrikas, 250. 
structures as in the French case. Second, this elite-making policy, pursued for the first time by the state, stood out for its single-mindedness: more than ever, in the Belgian Congo elite formation meant moralization and the cultural appropriation of the Catholic-bourgeois precepts inherent in the civilizing mission. The postulate of assimilation was linked with the promise of gradual equality - in contrast with the French Empire, in which cultural difference was no longer regarded as an impediment to legal integration or political participation. ${ }^{153}$ In common with the Portuguese territories in Africa, where the colonial subjects shared the fate of their counterparts in the metropolitan society in the sense that both were denied political rights under the internationally isolated dictatorship of António de Oliveira Salazar, Belgian colonial policy pursued a depoliticized and paternalistic reformist course. ${ }^{154}$ From now on, then, the Belgian Congo lagged behind colonial developments in the British and French African empires. Nonetheless, despite the slow pace of development and the territory's politically imposed seclusion, for both the Congolese elites and Belgian politicians the post-war elitemaking policy inspired a sense of new beginnings.

The Belgian Congo's integration into the Allied war economy had accelerated the social transformations of the inter-war period. Due to the war effort, between 1938 and 1945 the number of wage labourers had almost doubled to 800,000, an estimated 59 percent of the Congolese workforce. ${ }^{155}$ A quarter of the male population was engaged in hard labour in mines, plantations and infrastructure projects. ${ }^{156}$ The increased demand for labour also triggered rapid growth in urbanization. Before the war one in ten Congolese lived in urban settlements, while after it the figure had already grown to just under 15 percent. ${ }^{157}$ In Léopoldville the population trebled between 1935 and 1945 to 96,000, and five years later the figure was $191,000 .{ }^{158}$ Other provincial capitals also grew dramatically but had no more than 20,000 inhabitants each; the exception was Elisabethville in Katanga with 65,000. ${ }^{159}$

The war years also saw several strikes and instances of unrest. In Katanga UMHK workers demanded wage increases, food prices having risen exorbitantly due to the colony's economic isolation from continental Europe. A demonstra-

153 See Cooper, Citizenship.

154 This conclusion was reached at an early stage by Albertini, Dekolonisation, 585.

155 Vanthemsche, Genèse et portée, 7; Seibert, Globale Wirtschaft, 199.

156 Mutamba-Makombo, Du Congo belge, 22.

157 Ibid., 41.

158 J. S. Lafontaine, City Politics. A Study of Léopoldville (Cambridge: Cambridge University Press, 1970), 28.

159 Young, Politics, 207. 
tion in the provincial capital of Elisabethville was broken up with great brutality. ${ }^{160}$ As in other colonies, mutinies broke out among returning soldiers who had fought in Madagascar, Egypt, Ethiopia or Burma. ${ }^{161}$ The educated elite working in the administrative apparatus also began to make its voice heard. ${ }^{162}$ Shortly after the quelling of a mutiny among soldiers in the garrison town of Luluabourg in February 1944, a group of educated Congolese submitted a petition to the local district commissioner entitled Mémoire des évolués. The authors saw themselves as champions of a new social class that had set itself apart from the "masses" over the previous 15 years as "a kind of indigenous bourgeoisie": "The members of this indigenous intellectual elite do what they can to advance their education and to live as decently as the respectable Europeans." ${ }^{163}$ They demanded a number of privileges from the colonial administration: a special legal status, a regular audience with the provincial governor, better living conditions and transportation, greater recognition from the colonial officials who, they asserted, treated them like "savages," and measures to combat the abuse and insults they suffered at the hands of the European population. ${ }^{164}$ For the colonial authorities, the actions of the évolués and the uprisings of soldiers in Luluabourg were all of a piece, possibly orchestrated by Belgium's wartime enemies. This suspicion was reinforced by the fact that the main author of the memorandum, Etienne Ngandu, was a doctor's assistant who had returned from the war, in which he had led the African medical corps as sergeant major. ${ }^{165}$ The authors were banished to the backcountry. ${ }^{166}$

160 Ibid., 35. On the course of this demonstration and its influence on decolonization, see J. Seibert, "Winds of Change: Worker's Unrest and the Transformation of Colonial Capitalism in Katanga, Belgian Congo," in Travail et culture dans un monde globalisé. De l'Afrique à l'Amerique latine, eds. A. Eckert, B. Fall and I. Pfaff-Rheinberger (Paris: Karthala, 2013); Seibert, Globale Wirtschaft, 191-195.

161 On the uprisings in Masisi of March 1944, see Verhaegen, "Les associations congolaises," 390. On those in Elisabethville see Mutamba-Makombo, Du Congo belge, 36. In 1943 the Force Publique was made up of a total of 40,000 Congolese, but this figure included not just soldiers but also porters, and so on. After the war this figure decreased by half and reached the same level as before that conflict. See Mutamba-Makombo, Du Congo belge, 19.

162 Verhaegen, "Les associations congolaises," 389-390; Mutamba-Makombo, Du Congo belge, 39.

163 Memorandum from the évolués of Luluabourg to the district commissioner of Kasai, March 1944, quoted in Tshimanga, Jeunesse, 514.

164 Ibid.

165 Mutamba-Makombo, Du Congo belge, 44.

166 Ibid. 
Despite the repression, colonial officials and the cabinet of the Belgian exile government in London took the memorandum very seriously. ${ }^{167}$ For at about the same time groups of Congolese clerks in the provincial capitals of Elisabethville and Stanleyville had put forward similar demands. ${ }^{168}$ In Elisabethville a number of educated city dwellers had met with the publisher of a local newspaper, a periodical whose socialist and anti-capitalist views were unique in the colony, seeking publication of their letters of protest. ${ }^{169}$ This reinforced colonial officials' determination to push for closer integration of the évolués. Gustave Sand, who had received the memorandum as district commissioner in Luluabourg, addressed himself to the colonial minister in London: "We must attend to their moral education, their social and material life. They require a status of their own that sets them apart from the masses."170

A growing number of key actors called for the educated elite to be placed at the centre of colonial policy. While working closely with the General Government in Léopoldville, in a much-noticed article of 1943 liberal politician Robert Godding defended Belgium's "policy of the middle course, which takes account of the still primitive mentality of our black population as well as our concern to raise it gradually to a higher stage of civilization." ${ }^{171}$ He was, however, vociferous in advocating the advancement of a Congolese elite by channelling the "best pupils" into further education and administrative tasks. Godding's intervention mirrored the elite-making policy initiated by the General Government in Léopoldville during the final two years of the war. Colonial officials there were already grappling with the possibility of a special legal status for the elite, ${ }^{172}$ of the kind introduced

167 Minutes of cabinet meeting in London, 9 March 1944, 52, Archives de l'État.

168 Mutamba-Makombo, Du Congo belge, 57.

169 On the affiliations of Albert Decoster, his Echo du Katanga, founded in 1931, and the évolués' 1943 petition, submitted to that publication but censored by the authorities, see N. Esgain, "Scènes de la vie quotidienne à Elisabethville dans les années vingt," in Itinéraires croisés de la modernité Congo belge (1920-1950), ed. J.-L. Vellut (Paris: L'Harmattan, 2001), 69; J.-L. Vellut, “Albert Decoster," in Biographie Belge d'Outre-Mer, vol. 8, ed. Académie Royale Science d'Outre-Mer (Brussels: Librairie Falk fils, 1998), 80.

170 Report by Gustave Sand on the uprisings of 1944 in Luluabourg, quoted in Tshimanga, Jeunesse, 172.

171 R. Godding, "La politique indigène du Congo Belge," Croix du Congo, 16 January 1944. The quoted article is a translated version of an essay by Godding, which had originally appeared in the Belgian Revue Message under the title "The Congo in 1943 and After," a text distributed during the Belgian government's exile in London.

172 On the blueprint for a "special status" drawn up by the Affaires Indigènes et de la Maind'Oeuvre (AIMO) in January 1945, see E. T. A., "Évolution ou révolution," in Essor du Congo, 8 February 1945, reprinted in A. Rubbens, ed., Dettes de Guerre (Elisabethville: Editions de l'Essor du Congo, 1945), 126-127. 
by the French colonial government in neighbouring Brazzaville in $1942 .{ }^{173}$ In a similar vein Governor General Pierre Ryckmans initiated the establishment, throughout the colony, of newspapers and associations that explicitly sought to attract the French-speaking section of the Congolese population. The General Government was thus entering the terrain traditionally occupied by the Catholic missionaries, who had begun to address themselves to the graduates of their secondary schools using the same kind of approach in the 1930s. In the late colonial Congo, the colonial state essentially saw its elite-making policy as a means of getting the elite under control. Creating a new elite milieu was intended to facilitate the shaping and surveillance of educated Congolese lifeworlds and realms of discourse. On the model of Belgium elite formation meant constructing a societal pillar adapted to the colonial situation, one that was supportive of the state, supra-ethnic, Catholic, bourgeoisified and exclusive.

This state activism is testimony to the rethinking of Belgian colonial policy. Certainly, the colonial state continued to see educated and elite Africans as potential supporters of communist and anticolonial ideas. Belgian colonial policy, however, was put on the spot by reforms in other empires. Furthermore, qualified workers were required to implement the planned programmes of modernization, and here the educated elite provided key intermediaries. Under the watchful eyes of the UN, moreover, elite formation was intended to rebut the international community's claim that Belgian colonial policy had failed to promote the cultural and political development of the people of the Congo. At the end of the Second World War, Belgian politicians dedicated to colonial policy had come to regard a state push to promote a Congolese elite as unavoidable. What they could not know was that the future of Belgian colonial rule depended on their responses to the demands set out in the évolués' memorandum.

Belgian elite-making policy after 1945 was no longer focused on segregating the population based on ethnic criteria. Instead, it was centred on yardsticks of social ordering that made a dichotomous distinction between country and city, tradition and modernity, and progress and "backwardness." A rural population contrasted with a growing group of urban Congolese, with a small number of the latter standing out for their assimilation and education. ${ }^{174}$ In the inter-war period these assimilated Congolese were styled "detribalized," in other words in terms of what they "no longer" were. ${ }^{175}$ The term évolués that now took hold, mean-

173 Cooper, Citizenship, 26.

174 This was a conception of society that had also underpinned France's new Africa policy as announced in 1944. Cooper, Decolonization, 181; Cooper, Citizenship, 27.

175 Ibid., 12. 
while, underlined that this group was "not yet" fully developed. It was out of these so-called évolués that the colonial state set about forging an elite.

Who exactly was considered to be an évolué? This was an elite group within a Congolese workforce mainly employed in the agricultural and industrial sectors and often subject to forced recruitment. ${ }^{176}$ According to 1947 estimates, of the 750,000 wage labourers just 40,000 were évolués, working as office workers in the colonial administration or in companies, as doctors' assistants, teachers and foremen, or who had gained the qualifications needed for such work. ${ }^{177}$ Compared with the total population of more than ten million, ${ }^{178}$ this figure seems negligible. Relative to the just under 35,000 Europeans resident in Congo at the same time, ${ }^{179}$ however, what we find is a demographic dead heat that goes a long way to explaining not just the symbolic significance of the évolués in colonial discourse but also their importance - as a collaborative elite - to the maintenance of a colonial system that increasingly emphasized projects of modernization.

Moreover, the évolués constituted a steadily growing group of graduates of the missionary secondary schools. Following the period of expansion in the 1920s, across the colony there were just under a dozen schools of this type, most of them in the west, that is, in the capital of Léopoldville and the surrounding area. ${ }^{180}$ Between 1939 and 1948, 15,000 Congolese men successfully completed their studies at these educational establishments. ${ }^{181}$ The demand for office workers in particular had surged during the war years. Schools providing the relevant training had educated just 50 individuals in 1928, a figure that had increased to 330 by 1939 and 583 by $1943 .^{182}$ The term évolués denoted Congolese

176 De Schrevel, Les forces politiques, 85.

177 These are the figures quoted by J. Van Wing (J.Van Wing, "La formation d'une élite noire au Congo Belge" Bulletin C.E.P.S.I. 5 [1948]), missionary and member of the Conseil Colonial. They are fairly close to the official surveys on Congolese staff carried out by the colonial administration in 1946, though the categories the latter used hamper any attempt to specify occupational groups. One category identifies 18,396 administrative workers, while another lumps together mission staff, teachers and domestic workers $(146,290)$. There are no precise details on foremen or doctor's assistants. De Schrevel, Les forces politiques, 85.

178 Of which 33 percent were women, 31 percent men and 43 percent children. See ibid., 52. 179 Vanthemsche, La Belgique et le Congo, 404.

180 Boma and Léopoldville both had schools for office workers. There was a training centre focused on agriculture in Stanleyville, while schools for doctor's assistants were to be found in Léopoldville, Stanleyville and Kisantu, which was $50 \mathrm{~km}$ away from Léopoldville. The seminaries were in eastern Baudoinville and central Kabwe, among other locations; Mutamba-Makombo, "Les évolués," 95.

181 Mutamba-Makombo, Du Congo belge, 52.

182 Tshimanga, Jeunesse, 89. 
with a secondary education, that is, the group within the workforce with the highest income. At the top stood the office workers and bookkeepers who earned a monthly wage of 3,000 to 5,000 francs in the colonial administration and companies. Male nurses and factory foremen earned significantly less, the former 800 to 3,000 and the latter up to 1,725 francs. ${ }^{183}$ As a group office workers stood out not just with respect to their earnings but increasingly in numerical terms as well. During the war this category had grown by 70 percent to just under 15,$000 ;{ }^{184}$ by 1946 the figure had increased to $18,000 .{ }^{185}$ The late colonial elite was made up chiefly of civil servants responsible for minor administrative tasks, a phenomenon that extended to the African possessions of other European imperial powers. ${ }^{186}$ In contrast to colonies in West Africa, however, in the Belgian Congo no significant group of traders and entrepreneurs had developed that might have occupied an elite position on the back of economic success. ${ }^{187}$ This was due chiefly to the fact that the concessionary economy established in the days of the Congo Free State and the associated mobilization of wage labourers had systematically destroyed traditional trading networks. ${ }^{188}$ Even the retail trade was dominated by Greeks and Portuguese. ${ }^{189}$

Beyond a range of qualified, elite and educated occupational groups, the term évolués encompassed people of various regional, linguistic and ethnic backgrounds. Hailing from every part of the colony, the évolués embodied the fact that the Belgian Congo, as a centralized political construct, forced together highly heterogeneous population groups whose relationship to one another changed over the course of colonial rule. Certainly, the évolués were united by the French taught in secondary schools, but they came from the colony's more than 200 different linguistic communities, which took on new meanings as a result of colonial rule. Experiences of "being colonized"190 took very different forms in differ-

183 These are the figures for 1947. "Rapport de la mission senatoriale," quoted in Mutamba-Makombo, "Les évolués," 92. There is no data on primary school teachers.

184 Ibid.

185 De Schrevel, Les forces politiques, 85.

186 Tanganyika, for example. See Eckert, Herrschen.

187 On the example of the Gold Coast, see Kimble, A Political History of Ghana, 136; on the Duala in Cameroon, see Eckert, Grundbesitz.

188 Vanthemsche, Belgium and the Congo, 31; Seibert, Globale Wirtschaft, 223. The British Lever Brothers Limited had built up its palm oil production in the Belgian Congo since the 1910s because there, in contrast to the situation in Ghana and Nigeria, it faced no competition from local elites. Ibid., 143.

189 Young, Politics, 201. On the Portuguese community in the Belgian Congo, see J.-L. Vellut, Congo. Ambitions et desenchantements 1880-1960 (Paris: Karthala, 2017), 139-162.

190 Vansina, Being Colonized. 
ent regions. The extent to which, and at what point in time, the Congolese population entered into a "colonial relationship" based on inequality and domination depended first and foremost on their integration into "islands of colonial rule." ${ }^{191}$ Major cities, in which the administrative system and industry established branches and in which trade and transport routes converged, along with missionary secondary schools, were distributed unevenly in geographic terms. Inevitably, then, certain population groups gained more access to the colonial working worlds than others. As a group the évolués often included representatives of the so-called Bakongo, Bangala and Baluba. The Bakongo lived in the western part of the colonial territory between the Congo River's Atlantic delta and the capital, Léopoldville. The term Baluba was used for a geographically scattered group who, in an attempt to evade Swahili slave traders, had fled from the eastern areas in the 1880s, settling mainly in the central region of Kasai, where they found themselves in the territory of the Belgian missionaries established around the same time. ${ }^{192}$ The first European colonizers had included among the Bangala the heterogeneous communities living along the Congo River north-east of Léopoldville, particularly in Équateur quateur province. From the 1880s on the Force Publique had recruited its soldiers from among them, establishing Lingala as the language of the army and subsequently as a Congolese lingua franca. ${ }^{193}$

The emergence and establishment of these group designations was a colonial product. Ironically, it was the missionaries who had set out to bring Christian civilization to the world who studied local traditions and dedicated monographs to them, and whose knowledge shaped the genesis of modern anthropology. ${ }^{194}$ Most of the Belgian missionaries were Flemings and, inspired ideologically by the Flemish movement that had grown in strength during the First World War, in the Congo too they understood language as a people's soul. ${ }^{195}$ They gave the local dialects a written form, grouped them into supraordinate languages and used them in sermons and in primary education. ${ }^{196}$ They also observed, mapped, described and defined the cultural, legal and social

191 Pesek, Ende eines Kolonialreiches, 35.

192 Vansina, Being Colonized, 28.

193 Young, Politics, 240.

194 See P. Harries, “Anthropology,” in Missions and Empire, ed. N. Etherington (Oxford: Oxford University Press, 2005).

195 N. R. Hunt, "Rewriting the Soul in a Flemish Congo," Past \& Present 198, no. 1 (2008): 198. 196 B. Jewsiewicki, "The Formation of the Political Culture of Ethnicity in the Belgian Congo, 1920 - 1959," in The Creation of Tribalism in Southern Africa, ed. L. Veil (Berkeley: Currey University of California Press, 1991), 329. 
characteristics of the linguistic groups. Because the Belgian Congo was divided into the spheres of influence of the many missionary orders, those missionaries with an anthropological interest studied a variety of different groups. Jesuit Joseph Van Wing, whose order was responsible for the immediate surroundings of the capital Léopoldville, wrote multivolume works on the Bakongo who lived there, earning him membership of the Royal Anthropological Institute in London. ${ }^{197}$ He defined the Bakongo as descendants of the Congo Kingdom, which extended back into the fourteenth century and had been part of the transatlantic cultural world due to the Portuguese slave trade. The Scheut order was dominant in the provinces of Kasai, Équateur and Léopoldville, where its missionaries became chroniclers of the Baluba and Mongo, whose precolonial kingdom had occupied territory in central Congo south of the river. ${ }^{198}$ These ethnographically active missionaries taught the lessons, in French, in the small number of secondary schools. The ambivalent aspects of the notion of adaptation, straddling cultural civilizing and the preservation of tradition, shaped these missionaries' relationship to the Congolese elite. For example, in the seminary of Kisantu, Van Wing educated a generation of intellectuals who were subsequently employed in the administrative system and were proud both of their western education and of their status as Bakongo. In addition to the bourgeois and religious curriculum, the assimilated elite were also inculcated with a consciousness of those special aspects of their ethnic group the missionaries deemed worth preserving.

The educated Congolese addressed as a national elite by the colonial state after 1945 were confronted with a completely new concept of identity overarching the ethnic, linguistic, regional and missionary dividing lines within the colonial territory. In the model of the évolués the colonial state united the elites of a fragmented society like the parts of a broken vase; the glue was bourgeois morality, Catholic virtues and proximity to the colonial state.

For the first few years after the war the Colonial Ministry in Brussels supported the elite-building measures initiated by the General Government. During this period there was cross-party consensus on the need to satisfy the desires of the Congolese elite. ${ }^{199}$ In the socialist-liberal-communist governing coalition immediately after the war, which lasted from 1945 to 1947, liberal minister Robert Godding, who had helped determine the reformist course adopted during the war in Léopoldville, continued this elite-making policy. But Godding broke

197 Denis, "Van Wing," 461.

198 Young, Politics, 246-249.

199 Ibid., 74. 
with one of the basic tenets of Belgian colonial rule by providing Protestant mission schools with state funding for the first time. In four cities in the Congo, he also established secular grammar schools for European children and held out the prospect of similar establishments for their Congolese counterparts. Godding thus reinforced the Catholic missions' mistrust of the volatile governing constellations in Brussels, in which the PSC, as their patron and protector, was for the first time not involved. Certainly, even under the Liberals and following the expansion of the educational landscape - a process still informed by the precept of the gradual development of the overall population - the Catholic mission schools received the lion's share of state subsidies. ${ }^{200}$ Yet particularly with respect to elite-making policy, henceforth the colonial state and the missions competed for the same target groups, placing a question mark over the Catholic missions' monopoly in this regard.

With the PSC's victory in 1947, the Colonial Ministry's education policy was once again dedicated exclusively to advancing the existing Catholic-dominated school infrastructure. The three state grammar schools were an exception. ${ }^{201}$ As part of the Ten-Year Plan, expenditure on primary schools trebled in 1949 and the secondary schools expanded as well, but there was still no budget for higher education. The colonial state now increased its influence over teaching content: while missionaries were still allowed to teach in vernacular languages, the teaching of French began at a younger age. ${ }^{202}$

Under Colonial Minister Pierre Wigny of the Christian Social Party, the process of elite formation was highly paternalistic and assimilatory in character. Evidently, not only had specific elements of the metropolitan welfare state found their way to the Belgian Congo but so had the ideas of social order prevalent in post-war Belgium. While this neutral country had seen a comparatively small wartime decline in population, of 8,000 people, and its social structures had retained a certain stability during the occupation, ${ }^{203}$ its political and intellectual elites lamented that it had lost its way morally during the war; this allegedly found expression in increasing violence and criminality and in a more selfcentred and undisciplined society with a declining associational culture. Relationships between US-American soldiers and Belgian women outraged the leaders of the Catholic Church. ${ }^{204}$ The inter-war debate on the equality of the sexes

200 P. M. Boyle, "School Wars. Church, State, and the Death of the Congo," Journal of Modern African Studies 33, no. 3 (1995): 455.

201 Brassinne and Dumont, "Les autorités belges," 12.

202 Boyle, "School Wars," 456.

203 See Conway, Sorrows, 305.

204 Ibid., 311 and 314. 
also flared up again. In the Walloon areas women had taken over the work of men held captive during the war and throughout the country they demanded the right to vote. ${ }^{205}$ It was a European phenomenon that, in the eyes of the political elites, the Second World War had shattered an imagined social order. The Christian Democratic parties of Western Europe in particular came to power promising to restore this order. They not only touted social progress and reconciliation between the classes but also traditional familial models and conservative worldviews, and they combined the welfare state and the social market economy with an emphatically anti-communist stance. ${ }^{206}$ While elsewhere Christian Democratic parties were founded only in the post-war period, in Belgium the Parti Catholique, which could look back on 50 years of experience in government, reformed itself. The PSC, established in 1945, no longer saw itself as confessional, but as Christian, and sought to shake off its image as an advocacy group for the Catholic Church. In the shape of Christian personalism it pursued a third way beyond liberal capitalism and Marxist totalitarianism. ${ }^{207}$ The personalist social doctrine conceptualized individual freedom as the moral and material development of the person within societal frames of reference such as the nation, work, family and church. ${ }^{208}$ Due to an increasingly youthful party membership, many members had been socialized within Catholic Action and the JOC during the militant inter-war period, and they had grown to maturity with the idea that it was possible to change the entire society through Catholic values. $^{209}$ The party's founding manifesto referred to "Christian civilization" and to the duty "to reconstruct a new society in the coming generations [the old society having been] fundamentally unsettled by the war."210

In the 1947 election the PSC assured itself of victory by advocating a reform programme that aimed to advance the welfare state and stimulate industrial development. It also benefited from the general population's greater orientation towards religious faith in the immediate post-war period, which had gone hand in hand with Catholic-dominated public debates on the cementing of the tradition-

205 Ibid., 296.

206 T. Judt, A History of Europe since 1945 (London: Penguin, 2005), 80 - 81; M. Conway, "Introduction," in Political Catholicism in Europe, 1918-1965, eds. T. Buchanan and M. Conway (Oxford: Oxford University Press, 1996), 30.

207 Conway, "Belgium," 209.

208 F. Floré, "Promoting Catholic Family Values and Modern Domesticity in Postwar Belgium," in Negotiating Domesticity. Spatial Productions of Gender in Modern Architecture, eds. H. Heynen and G. Baydar (New York: Routledge, 2005), 85.

209 On the party's relaunch, see V. Dujardin and M. Dumoulin, L'union fait-elle toujours la force? (Brussels: Le Cri, 2008), 111; Conway, Sorrows, 211.

210 Quoted in Delwit and Hellings, "Du parti catholique," 17; Conway, Sorrows, 194. 
al marriage - featuring a male breadwinner and a stay-at-home wife looking after household and children - and conventional gender relations more broadly. ${ }^{211}$ The initial coalition with the Socialists was based on a common front against the PCB, whose brief surge in electoral support seemed threatening in light of the intensifying confrontation between the capitalist communist worlds. Helped by the reconstruction of party-oriented socioeconomic and cultural networks, the rival PSC and PSB managed to attract the support of between 75 percent and 80 percent of voters once again. ${ }^{212}$ The "repillarization" of the fragmented society was complete. ${ }^{213}$ When the PSC achieved an absolute majority in 1950, its welfare policies sought to consolidate the bourgeois nuclear family underpinned by Christian values.

In contrast to the situation in Great Britain, however, Belgium's colonial possessions appear to have played no role in the country's post-war debates on the gradual introduction of the welfare state. ${ }^{214}$ Likewise, the question of a specific legal status for the Congolese elite was not subject to an overarching discussion of imperial citizenship that might have brought the metropolitan and colonial population into a common frame of reference, as in the case of the Union Française. ${ }^{215}$ The Belgian state continued to keep the colonial and national political fields separate. The formation of a Congolese elite was the business of the Colonial Ministry. Nonetheless, we can discern common ground between these two spheres in socio-political terms. Against the background of the looming Cold War, liberal, Catholic and socialist parties were as one in their bourgeois desire to rein in Belgian society and integrate it politically through welfare policy and a national education policy- in significant part by re-pillarizing the various milieus. ${ }^{216}$ In the Congo, by "improving [their] moral, social and material existence," the General Government aimed to achieve content colonial subjects who would be less susceptible to the feared communist infiltration. ${ }^{217}$ The Ten-Year Plan, accordingly, promised to ensure the Congolese population's goodwill and allegiance.

211 Ibid., 195 and 304-305.

212 Ibid., 177.

213 Ibid., 206.

214 Vanthemsche, Belgium and the Congo, 47.

215 On the French case, see Gosewinkel, Schutz und Freiheit?, 318.

216 See Conway, Sorrows, 9.

217 Letter from Vice-Governor General Léon Pétillon to the provincial governors, 30 May 1947, quoted in A.-S. Gijs, Le pouvoir de l'absent: Les avatars de l'anticommunisme au Congo (19201961) (Brussels: Peter Lang, 2016), 161. 
The first Christian Social colonial minister, Pierre Wigny, who had gained a PhD in law from Harvard and was co-author of the PSC's founding manifesto, ${ }^{218}$ oriented his elite-making policy towards opinion leaders in the General Government who regarded the "total assimilation of the indigenous population as the inevitable result of our colonial policy." 219 In this context the évolués were considered the vanguard of, and developmental model for, a future Congolese society. In accordance with this personalistic conception of human beings, it was their national duty to "advance along the arduous path of civilization" within their familial, occupational and religious lifeworlds. ${ }^{220}$ Overall, the developmental colonialism pursued in post-war Africa reflected the state's aspiration to organize, mould and control the colonial societies. ${ }^{221}$ The objective of late colonial "social engineering" was to "re-educate [Africans] as urban residents"222 and to hasten the emergence of a new "modern African." 223 The cementing of gender roles in the shape of a working husband and a home-making wife stood centre stage here.

After 1945 Belgium's colonial policy, which was heavily social interventionist in comparison to that of other empires when it came to social affairs, took on a new set of emphases. ${ }^{224}$ Under the watchful eye of the international community, Belgium's official colonial paradigm posited Congolese society's capacity for cultural development and potential for social progress. However, as Frederick Cooper has underlined with respect to the 1940s and 1950s, in the eyes of the late colonial authorities it was in fact so-called "African culture" and "tradition" that stood in the way of progress. The concept of scarcely surmountable cultural differences supplanted the notion of unchangeable and quasi-biological differences supposedly inherent in "race." Theoretically, then, civilizational development

218 On Wigny's biography, see A. Stenmans and J. Charlier, "Pierre Wigny," in Biographie Belge d'Outre-Mer, vol. 9, ed. Académie Royale des Sciences d'Outre-Mer (Brussels: Librairie Falk fils, 2015).

219 P. Piron, "L’évolution des populations détribalisés," Congrès Colonial National, Les évolués (n.d.), 27. The jurist Piron was tasked with drawing up a legal reform tailored to the Congolese elite, initially by the General Government in Léopoldville and subsequently by Colonial Minister Wigny; See A. Rubbens, "Pierre Piron," in Biographie Belge d'Outre-Mer, vol. 7-B, ed. Académie Royale des Sciences d'Outre-Mer (Brussels: Librairie Falk fils, 1977).

220 J.-M. Domont, Élite noire (Brussels: Office de Publicité, 1948), 131.

221 Cooper, Decolonization, 173.

222 Eckert, "Wohlfahrtsmix," 105.

223 Ibid.

224 Cooper, Africa since 1940, 63. For the Belgian Congo, see M. Bandeira Jerónimo, "Restoring Order, Inducing Change: Imagining a 'New (Woman)' in the Belgian Colonial Empire in the 1950s," Comparativ 28, no. 5 (2018). 
was open to anyone who assimilated and dissociated themselves from African culture. ${ }^{225}$ In Belgian developmental colonialism the civilizing mission's precept of assimilation underwent a major re-flowering. With its notion of the individual's capacity for development, in ideological terms the post-war civilizing mission resembled the pre-Darwinist model of the early nineteenth century. ${ }^{226}$ At the same time, the notion of the successive civilizational development of Congolese society tallied with the faith in progress so characteristic of modernization theory. In the debate on elite-making policy, missionaries, politicians concerned with colonial policy and educated Congolese used terms such as progress, development and civilizing synonymously. The vernacular elite was to provide the model pupils for a Belgian civilizing mission that took on the air of a project of moralization.

However, in the Belgian Congo the first group that had to satisfy the state's aspirations for a moral and bourgeoisified class was not the new Congolese elite. Instead, within colonial discourse this group was viewed as an extension of a "colonial elite" that, until 1945, included only Europeans resident in the colony, be they settlers, merchants or administrative workers. ${ }^{227}$ The evidence, particularly from the 1910s onwards, shows that the Belgian colonial state increasingly evaluated Europeans' conduct through criteria of morality and bourgeois culture. The Colonial Ministry, for example, paid greater attention to the professional and moral education of future colonial officials in special training centres. Certainly, it was already one of the basic principles of colonial ideology that the prestige and respectability of colonialism depended in part on the resident European actors' conduct and lifestyle. But the Belgian state had taken over the Congo in 1908 as Leopold II's infamous colony and, in view of the history of atrocities, other European colonial powers were vocal in questioning its capacity for colonization. Belgium was thus especially keen for the Europeans to demonstrate exemplary conduct. The "refinement of the leading European cadres" 228 and the recruitment of a "moral elite" 229 were attempts to demonstrate the respectability of

225 Cooper, Decolonization, 17.

226 On the various rationales put forward for the civilizing missions, see Barth and Osterhammel, Zivilisierungsmissionen.

227 On the following remarks, see A. Lauro and V. Piette, "Le Congo Belge. Coloniser sans élites?,” in Au sommet de l'Empire. Les élites européennes dans les colonies (XVIe-XXe siècle), eds. C. Laux et al. (Brussels: Peter Lang, 2009).

228 This was the term for these actors in administrative correspondence around 1915. Quoted in ibid., 127.

229 Ibid., 129. 
Belgium's colonial project to those colonial powers that were sceptical about it. $^{230}$

Hence, when the colonial state addressed itself to the Congolese elite as a moral grouping, this was in continuity with its programmes to foster an exemplary Belgian colonial elite. Yet for the African elite the Europeans were a highly ambivalent role model. That Europeans were to play this role for the upper echelons of African society was an expression of the ideology of colonial civilizing missions. Ever since France had declared the civilizing of colonized peoples the duty of the European states around 1870, the civilizing mission had served as a legitimizing strategy for European colonialism. The supposedly primitive colonial subjects were to be raised up, on the model of a superior European culture, so that they could one day govern themselves. ${ }^{231}$ It was Africans' responsibility to learn the lessons of civilized life through assimilation, in other words by imitating Europeans. Colonial ideologues conceived of this assimilation as a one-sided learning process. Conversely, imitation was a thorn in their flesh whenever young male Europeans in remote colonial outposts, without a family or reference group, associated with Africans and adopted local habits and customs. ${ }^{232}$ Verkaffern was the disparaging term used by the German press around 1900 to convey these processes of cultural adaptation to the African population among Europeans. ${ }^{233}$ The trope of assimilation dominant within colonial discourse was a normative one and referred exclusively to Africans' continual learning from the example of a respectable European. By creating a colonial elite of Congolese, the Belgian colonial state expected nothing less than a new group of intermediaries that would aid its civilizing mission. The image of Congolese society underpinning this policy assumed that it was divided into a small assimilated elite and an uneducated mass. ${ }^{234}$ Henceforth, the Congolese moral elite was to play the role that had previously been the preserve of the Europeans in the colony, namely that of civilizational role model. To the extent that the indigenous politics of

230 A. Lauro, "Les politiques du mariage et de la sexualité au Congo Belge (1908-1945): Genre, race, sexualité et pouvoir colonial” (PhD diss., Université libre de Bruxelles, Brussels, 2010), 551. 231 On the French civilizing mission, see Conklin, A Mission to Civilize, 1-10. A good overview is provided by A. Eckert, "Die Verheißung der Bürokratie. Verwaltung als Zivilisierungsagentur im kolonialen Westafrika," in Zivilisierungsmissionen. Imperiale Weltverbesserung seit dem 18. Jahrhundert, eds. B. Barth and J. Osterhammel (Konstanz: UVK, 2005).

232 Saada, “Entre ‘assimilation' et 'décivilisation,”' 28-30.

233 Conrad, Kolonialgeschichte, 75.

234 Here we can discern parallels with the welfare programmes in British colonies. In light of the case of Tanganyika Andreas Eckert shows that the colonial social policy pursued by the British after 1945 sought, with moderate success, not just to integrate the war veterans but also to close the gap between proletariat and elite. See Eckert, "Wohlfahrtsmix," 111. 
the post-war era presented the mass's imitative approximation of the vernacular elite as an ideal, the task of cultural assimilation through social interaction passed to this top level of African society. In short, the African elite was to be bourgeoisified so that it in turn could carry out the task of bourgeoisification. It was to be moralized in order to moralize.

However, the elite's delegated function as role model stood in contrast to what sociologist Emmanuelle Saada calls "maintaining a safe distance."235 In practice everyday interaction between Africans and Europeans, as presupposed by assimilation theory, was very limited and mostly took place in mission schools or workplaces. Yet the missionaries in their vestments, who preached the ideal of civilized European masculinity to educated Africans, were a rather poor role; many young urban men regarded them as "bearded women." 236 In addition, the institutionalized separation of lifeworlds was an impediment to social interactions, as in the case, for example, of a form of urban planning that segregated the residential quarters and recreational sites of Europeans and Africans. At the same time, the Belgian colonial state fostered the "bourgeoisification of the colonized communities."237 Hence, restrictive immigration laws prohibited the settlement of destitute or lower-class Belgians and provided for the expulsion of Europeans who cultivated a lifestyle displeasing to the colonial administration - because it contradicted the ideal of a moral elite as the highest stage of civilization. Time and again the colonial authorities were scandalized by the "lack of decency" 238 shown by their officials, most of whom had arrived in the colony as single men and were conspicuous for their excessive consumption of alcohol, ${ }^{239}$ entering into sexual relationships with Congolese women and their excessive violence. ${ }^{240}$ In the eyes of the authorities this conduct disrupted the colonial order. ${ }^{241}$ Tellingly, the resistance of Congolese to behavioural change was said to be the result of Europeans' poor conduct. ${ }^{242}$ In much the same way as other European colonial powers, after the First World War Belgian grad-

235 Saada, “Entre ‘assimilation' et 'décivilisation,”” 30.

236 Gondola, Tropical, 10.

237 Lauro and Piette, "Le Congo Belge," 125.

238 Lauro, "Politiques," 552.

239 On the alcohol consumption of Belgian colonial officials, see A. Vleugels, Narratives of Drunkenness, Belgium 1830-1914 (London: Routledge, 2015), 99-102.

240 For a general account of Europeans in the colonies, see Conrad, Kolonialgeschichte, 75-79. On the excessive violence and abuse of power among German colonial officials in Togo, see R. Habermas, Skandal in Togo. Ein Kapitel deutscher Kolonialherrschaft (Frankfurt am Main: S. Fischer, 2016).

241 Lauro, "Politiques," 52 and 552.

242 Ibid., 551. 
ually began to support the settlement of women from the metropole, which promised to facilitate the import of a respectable "bourgeois European family" to the Congo and was also intended to impede relationships between European men and Congolese women. ${ }^{243}$ While 9,000 of the 25,000 Europeans in the Congo were women and children in 1930, the latter group made up 24,000 out of 43,408 individuals by $1948 .^{244}$ The emergence of residential districts for European families and other socially exclusive forms of community formation for the European colonial population exacerbated the segregation within the rapidly growing cities. ${ }^{245}$

Hence, the promotion of the Congolese elite as practised within Belgian colonial policy after 1945 involves a paradox. On the one hand, the colonial habitus $^{246}$ of the European population and the bourgeois culture that it entailed embodied the ultimate objective of the civilizing mission. ${ }^{247}$ On the other hand, the colonial habitus was a means of cultural distinction inherent in European rule, whose legitimization required the everyday staging of civilizational superiority vis-à-vis Africans. The European colonial elite, then, was both a shining example and the custodian of hierarchical difference. The évolués, who were addressed by the colonial state as an elite, were supposed to emulate an ideal of European bourgeois culture. Yet in order to maintain the colonial order it was vital that they never fully measure up to it. ${ }^{248}$

243 Lauro and Piette, "Le Congo Belge," 134-135. On the example of German South West Africa, see K. Walgenbach, "Die weiße Frau als Trägerin deutscher Kultur.” Koloniale Diskurse über Geschlecht, "Rasse” und Klasse im Kaiserreich (Frankfurt am Main: Campus 2005), 83-88.

244 Vanthemsche, La Belgique et le Congo, 403-404.

245 Gondola, Tropical, 38; A. Lauro, Coloniaux, ménagères et prostituées au Congo belge (18851930) (Brussels: Labor, 2005), 45.

246 On the "metropolitan habitus," see M. Pesek, "Die Kunst des Reisens. Die Begegnung von europäischen Forschungsreisenden und Ostafrikanern in den Kontaktzonen des 19. Jahrhunderts," in Erinnerungsräume und Wissenstransfer. Beiträge zur afrikanischen Geschichte, eds. W. Speitkamp, J. Reulecke and B. Neumann (Göttingen: Vandenhoeck \& Ruprecht, 2008); M. Pesek, "Performing the Metropolitan Habitus. Images of European Modernity in Cross-Cultural Encounters in Nineteenth Century Eastern Africa," in Figurations of Modernity. Global and Local Representations in Comparative Perspective, eds. V. Houben and M. Schrempf (Frankfurt am Main: 2008).

247 Pesek, Ende eines Kolonialreiches, 32-33; A. L. Stoler, "Rethinking Colonial Categories. European Communities and the Boundaries of Rule," Comparative Studies in Society and History 31 (1989): 137.

248 Eckert, “Verheißung der Bürokratie,” 271. 